\title{
Groundwater chemistry evaluation for drinking and irrigation utilities in east Wasit province, Central Iraq
}

\author{
Hussein B. Ghalib ${ }^{1}$
}

Received: 4 December 2016/Accepted: 11 May 2017/Published online: 20 May 2017

(c) The Author(s) 2017. This article is an open access publication

\begin{abstract}
The present study focused on assessing the groundwater quality of the shallow aquifer in the northeastern Wasit Governorate, Iraq. The physicochemical parameters, including major cation and anion compositions, $\mathrm{pH}$, total dissolved solid and electrical conductivity, were used to assess the suitability of groundwater quality for drinking purpose by comparing with the WHO and Iraqi standards. Total dissolved solid (TDS), sodium adsorption ratio, residual sodium bicarbonate, permeability index and magnesium ratio were used for irrigation suitability assessment. For this purpose, 98 samples were collected from the scattered shallow wells in the study area. Results indicated that the spatial distribution of TDS, EC values and major ions in these groundwater samples considerably differ from one site to another mainly due to the lithological variations of the area. The results are correlated with standards classifications to deduce the hydrogeochemical phenomena. The dominant factors in controlling the groundwater hydrogeochemistry are evaporation and weathering in the study area. Geochemical modelling approach was used to calculate the saturation state of some selected minerals, i.e., explaining the dissolution and precipitation reactions occurring in the groundwater. The studied groundwater samples were found to be oversaturated with carbonate minerals and undersaturated with evaporates minerals. A comparison of groundwater quality in relation to drinking water standards showed that most of the groundwater samples were unsuitable for drinking purposes. On the other hand, most groundwater is
\end{abstract}

Hussein B. Ghalib

hbggeo@gmail.com

1 Department of Geology, College of Sciences, University of Basrah, Basra, Iraq unsuitable for irrigation purposes based on sodium and salinity hazards. However, soil type as well as proper selection of plants should be taken into consideration.

Keywords Groundwater quality · Wasit . Hydrogeochemistry $\cdot$ Saturation index $\cdot$ Groundwater suitability $\cdot$ Iraq

\section{Introduction}

Groundwater is the important source of water used for human utilization and for both industrial and agricultural activities in regions where surface water is scarce (Delgado et al. 2010). It plays an important role for society, economy and ecology developments. In arid zones, water is a rare and precious resource. The demand for water has rapidly increased over the past few years and this has resulted in water scarcity in many parts of the world. Due to the fact that Iraq is an arid country at least in the central and southern parts, this country is heading towards a water crisis mainly due to the improper management of water resources, water policies in neighbouring countries (Turkey, Syria, and Iran), and the prevalence of drought conditions caused by climatic changes. During the past few decades, groundwater levels in main freshest aquifer in Iraq have been falling due to the increase in extraction rates and very bad management scenarios. The rapid increase of population associated with changing lifestyles, especially after 2003, has also increased the domestic, agricultural and industrial usage of groundwater in entire Iraq, particularly in central and south Iraq. The contamination of these aquifers has also added another dimension for the problem for decision maker and politicians (Al-Abadi 2012). To utilize and protect valuable water sources effectively and 
predict the change in groundwater environments, it is necessary to understand the hydrochemical parameters of groundwater such as $\mathrm{pH}$, electrical conductivity (EC), total dissolved solids (TDS), sodium absorption ratio (SAR), total hardness (HT), major anion $\left(\mathrm{CO}_{3}{ }^{2-}, \mathrm{HCO}_{3}{ }^{-}, \mathrm{Cl}^{-}\right.$and $\left.\mathrm{SO}_{4}{ }^{2-}\right)$ concentrations, and major cation $\left(\mathrm{Ca}^{2+}, \mathrm{Mg}^{2+}\right.$, $\mathrm{Na}^{+}$and $\mathrm{K}^{+}$) concentrations (Edmunds et al. 2006; Guendouz et al. 2003; Prasanna et al. 2010). Water quality gets modified along the course of movement of water through the hydrological cycle and through the operation of the following processes: evaporation, transpiration, selective uptake by vegetation, oxidation/reduction, cation exchange, dissociation of minerals, precipitation of secondary minerals, mixing of waters, leaching of fertilizers and manure, pollution and biological processes (Appelo and Postma 2004). Many geological and geo-structural studies have been conducted on the Wasit area (Enad 2007; Hassan 1985; Macfadyen 1935; Parson 1955). The hydrogeological studies are still limited (Al-Abadi 2015; AlAzawi 2002; Al-Furat Center Company for study and design irrigation projects 2002; Hassan et al. 1977). Studies about hydrogeochemistry in the whole region are very limited (Al-Shammary 2006; Ali and Ali 2013). In the study area, agriculture is the most important economic activity; thus, a hydrogeochemical investigation was carried out to identify groundwater geochemistry and its suitability for irrigation and drinking purposes.

\section{The general description of study area}

The study area extends over an area of $1164.48 \mathrm{~km}^{2}$ and lies between $33^{\circ} 00^{\prime}$ and $33^{\circ} 20^{\prime}$ latitude and $45^{\circ} 50^{\prime}$ and $46^{\circ} 15^{\prime}$ longitudes in the northeastern Wasit Governorate, Iraq (Fig. 1). It is bounded by Iraqi-Iranian border (Hamrin hills) from the east, Wadi Galas from north, and Hor Al Shiwach from east and south. The main two cities within the question area are Badrah and Jassan. The major portion of the study area is flat and featureless. Relief is low with only a few isolated hills rising above the general level of the plain in the east (Parsons 1956). Three quarters of the study area are plain with a gentle slope and occupy the southwestern parts. The remaining quarter locates in the northeastern part and roughly parallel to the Iranian borders and is characterized by low anticlinal folds with intervening synclinal valleys (Parsons 1956). Elevation in the study area ranges from 0 to $318 \mathrm{~m}$ with an average of $70 \mathrm{~m}$ above sea level, (Fig. 2). The study area is generally hot and dry. It is characterized by absence of rainfall in summer (June-September) with rainy season beginning from autumn to spring (October-May). The area receives an average annual rainfall of approximately $212 \mathrm{~mm} /$ year with an uneven rainfall distribution between plain and mountain parts. According to the recorded meteorological data in Badra station for the period (1994-2013), the monthly maximum, minimum and average temperatures are $10.4,37.8$ and $24.56^{\circ} \mathrm{C}$, respectively. Drainage in the question is almost in a southwesterly direction (Parsons 1956). The nature of the Galals or streams is intermittent and terminates in the temporary marshes on the delta plain. During heavy rainfall periods, the coming flooding water from the Iranian side submerges the flat plain to the west, causing occasional floods. The major stream in the study area is Galal-Badra River. The mean monthly discharge of this river is 2.5 and $1000 \mathrm{~m}^{3} / \mathrm{s}$ in drought and flood periods, respectively (Al-Shammary 2006). Due to the prolonged drought conditions and intermittent nature of the streams in the study area, most of the farmers depend on the groundwater for their irrigation needs. From a geological point of view, rocks in the investigated area range in age from Upper Miocene to Recent. In the western portion, the younger rocks are exposed and increasingly become old to the east. Most of the area is covered by rocks of alluvial and lacustrine origin, Pliocene or younger in age. The stratigraphic succession is composed of Injana, Mukdadiya formations in addition to the quaternary deposits. The quaternary deposits mainly consist of a mixture of gravel, sand, silt and conglomerates of post Pliocene deposits. The distribution of these lithological units is shown in Fig. 3. A brief description of these units is provided in Table 1 . Approximately $84 \%$ of the study area is covered with quaternary deposits. Tectonically, the platform of the Iraqi territory is divided into two basic units, the stable and unstable shelf (Jassim and Goff 2006). The stable shelf is characterized by reduced thickness of the sedimentary cover and by the lack of folding, while the unstable shelf has a thick and folded sedimentary cover. Folds are arranged in narrow long anticlines and broad flat synclines (Al Sayab et al. 1983).

The greater parts of the study are located in the stable shelf (Mesopotamian plain) and only a small part extends over the unstable shelf close to the Iraqi-Iranian border (folded zone). There are many faults in the study area, and the bigger and important one is Shbichia-Najaf fault. The soil of the study area is formed from the processes of weathering, erosion and sedimentation during the quaternary period.

To indicate the minimum rate of infiltration for bare soil after prolonged wetting (USDA 1986). The four hydrologic soils groups are A, B, C and D, where A generally has the greatest infiltration rate (smallest runoff potential) and $\mathrm{D}$ the smallest infiltration rate (greatest runoff potential) (AlAbadi 2012). The hydrologic soil group map of the study area is shown in Fig. 4, in which the major portion of the study area (about $60 \%$ ) has high infiltration rate (A and $\mathrm{B}$ groups). The aquifer system in the study area consists of two hydrogeological units. The first one represents the 


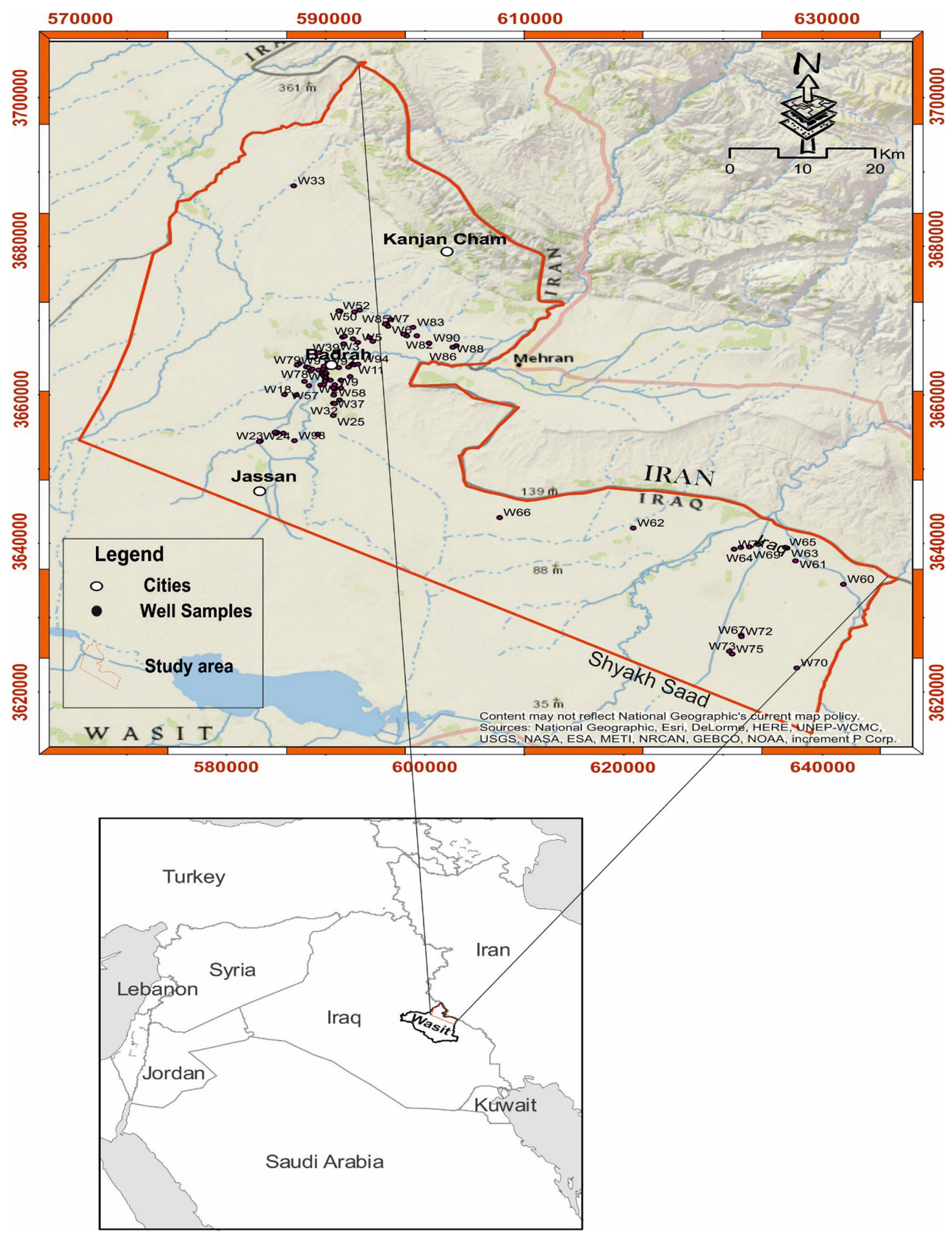

Fig. 1 Location map of the study area 


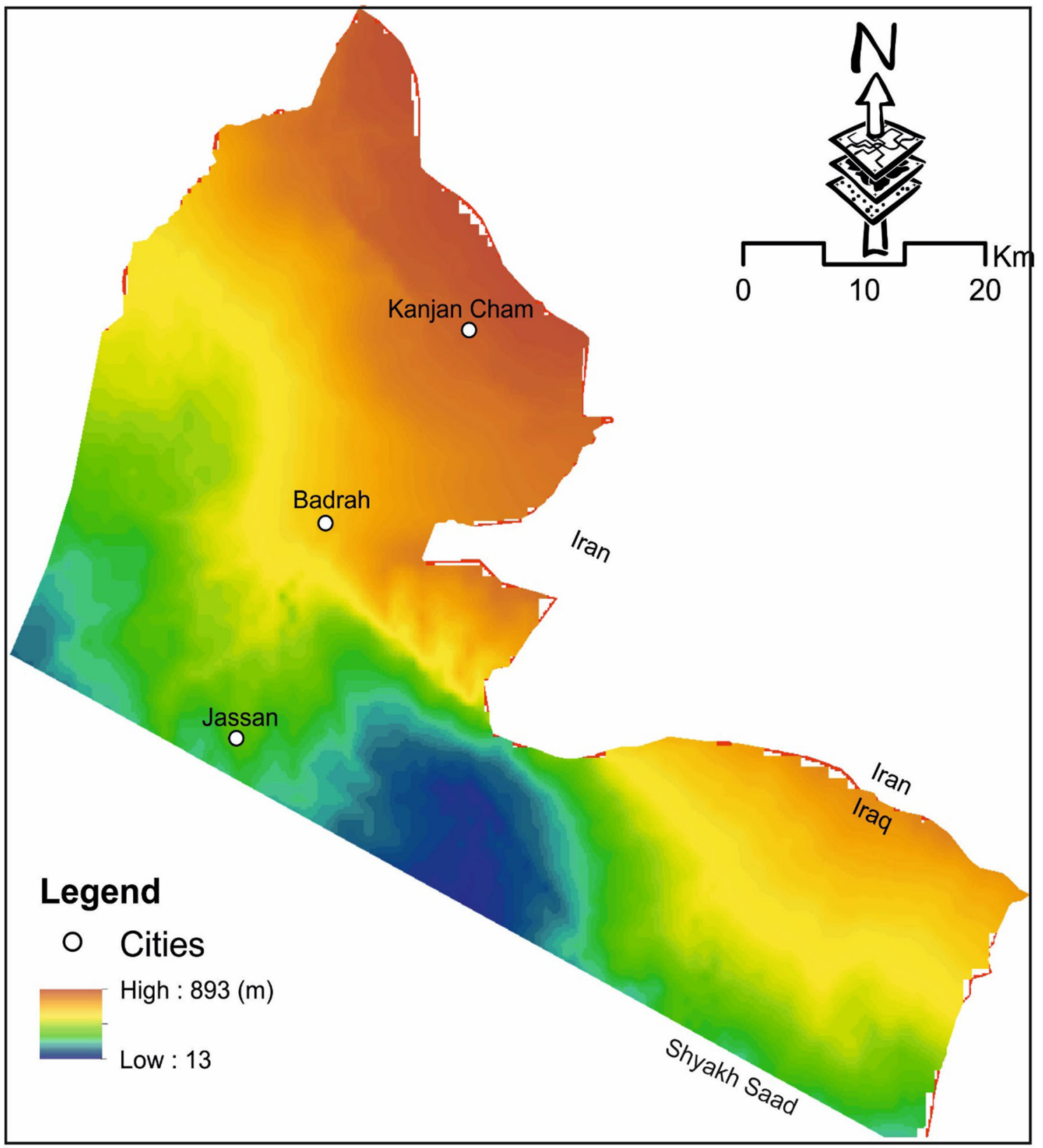

Fig. 2 Ground surface elevation of the study area (extracted from DEM with $30 \mathrm{~m}$ resolution)

shallow unconfined aquifer consisting mainly of layers of sand, gravel with overlapping clay and silt. This hydrogeological unit is located within the quaternary lithological layers. The second hydrogeological unit is Mukdadiya water bearing layer. The aquifer condition of this unit is confined/semi-confined. The regional groundwater flow is from northeast to southwest. Depths to groundwater range from 26 to $162 \mathrm{~m}$. The spatial distribution of the groundwater depths in the study area is shown in Fig. 2, in which the groundwater depths increase towards eastern and northeastern parts corresponding to the elevation increase in the same directions. The hydraulic characteristics of the two hydrogeological units were estimated by Al-Shammary (2006) by means of pumping test. For the unconfined aquifer, the hydraulic conductivity, transmissivity and specific yield were $6.3,228.43 \mathrm{~m}^{2} /$ day and 0.012 , respectively. For the confined aquifer the values were 3.5, $81.07 \mathrm{~m}^{2} / \mathrm{day}$, and 0.0017 for hydraulic conductivity, transmissivity and storage coefficient, respectively. The spatial distributions of transmissivity and storativity for the whole aquifer system are shown in Figs. 6 and 7. In general, the hydraulic characteristics of the aquifer system are good in the middle and western side of the study area and become poor in the eastern parts. 


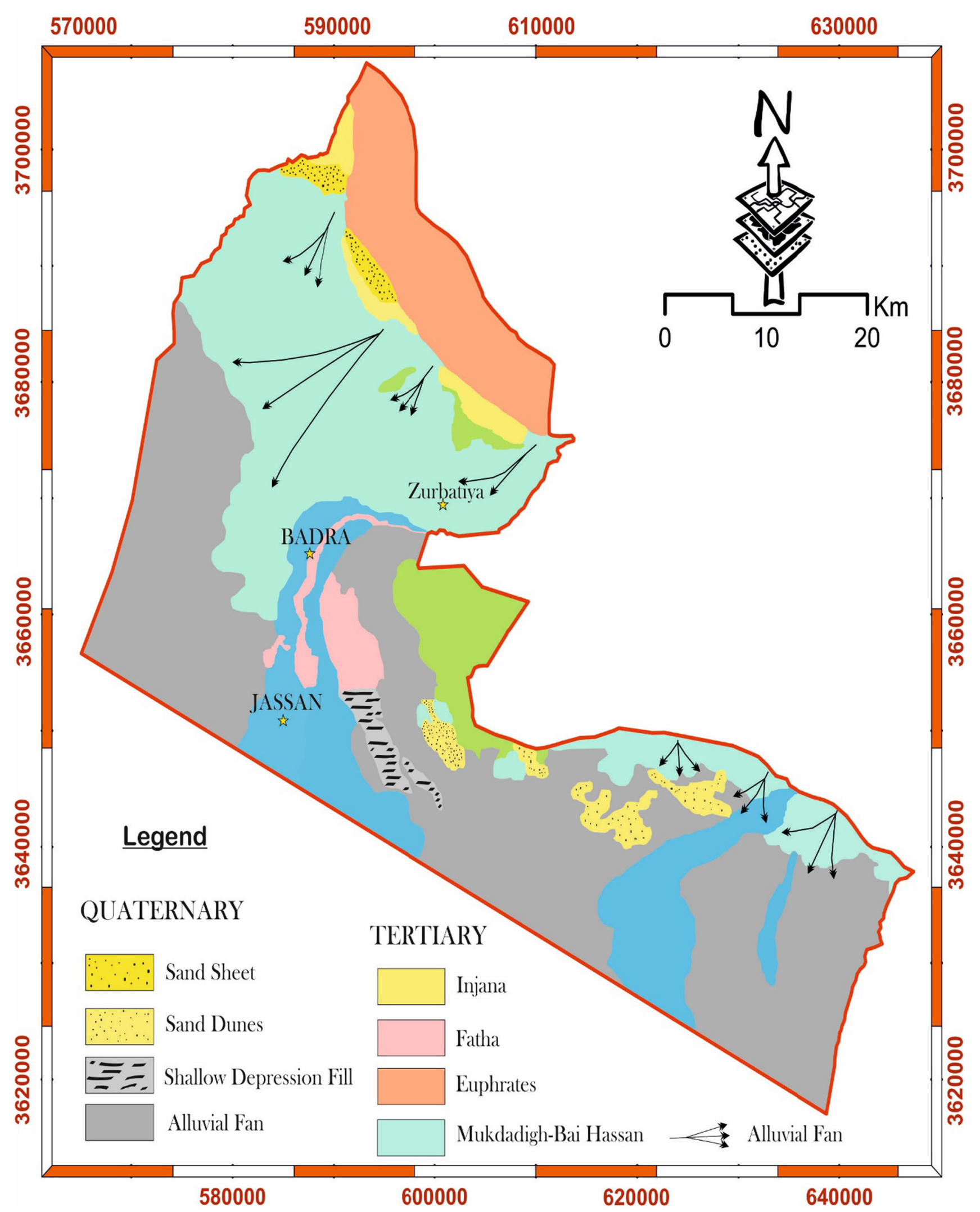

Fig. 3 Geological map of the study area 
Table 1 Description of the lithological formations in the study area

\begin{tabular}{|c|c|c|c|c|c|}
\hline Formation & Age & Environment & Description & Area $\left(\mathrm{km}^{2}\right)$ & Area $(\%)$ \\
\hline Injana & Upper Miocene & Sub-marine & Red or grey coloured silty marl or clay stones and purple silt stones & 8 & 0.01 \\
\hline Muqdadyia & Pliocene & Continental & Gravely sandstone, sandstone, and red mudstone & 103 & 0.15 \\
\hline Quaternary & $\begin{array}{c}\text { Pleistocene- } \\
\text { Holocene }\end{array}$ & Continental & Mixture of gravel, sand, silt and clay & 596 & 0.84 \\
\hline
\end{tabular}

Fig. 4 Box and whisker plot for the chemical constituents

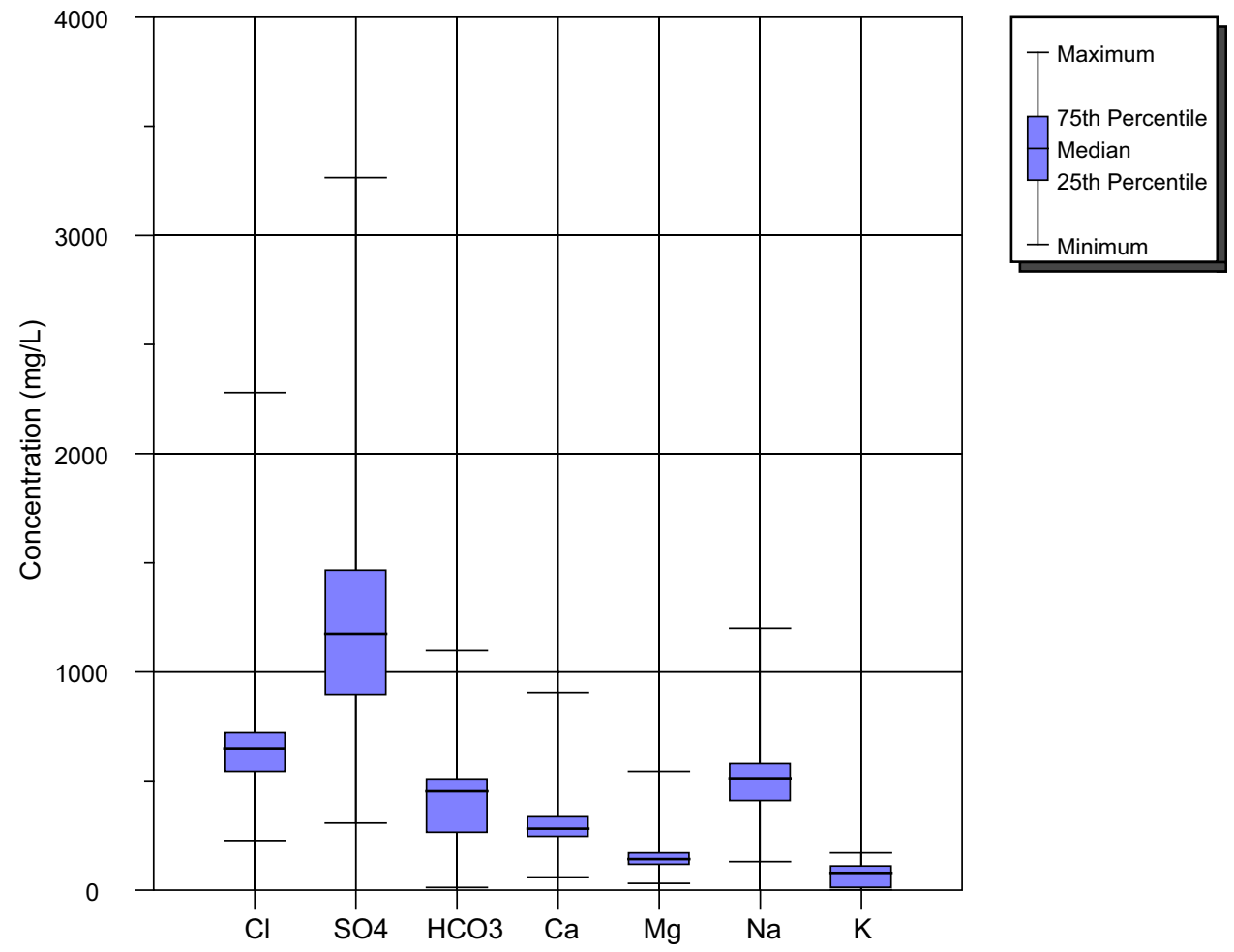

\section{Materials and methods}

A total of 98 groundwater samples were collected from the unconfined aquifer of the quaternary deposits for period 2013 (Fig. 1). The samples were analysed using standard procedures (APHA 1998). Major cations such as $\mathrm{Ca}$ and $\mathrm{Mg}$ were analysed by titrimetry, $\mathrm{Na}$ and $\mathrm{K}$ by flame photometer (Elico CL 378), major anions $\mathrm{Cl}$ and $\mathrm{HCO}_{3}$ by titrimetry, and $\mathrm{SO}_{4}, \mathrm{PO}_{4}$ and $\mathrm{H}_{4} \mathrm{SiO}_{4}$ by spectrophotometer (SL 171 minispec). EC and $\mathrm{pH}$ were determined in the field itself using electrode (Thermo). The total cation $(\mathrm{Tz}-)$ and total anion (Tz-) balance (Domenico and Schwartz 1998; Freeze and Cherry 1979) is considered to show the ionic balance error percentage. The error percentage in the samples ranged from \pm 1 to $\pm 10 \%$. The results of chemical analysis of groundwater samples with useful statistics are summarized in Table 2. The spatial distribution of the chemical constituents was investigated using stochastic ordinary kriging interpolation technique in Geostatistical extension of ArcGIS 10.3.3 software after a detailed data exploratory analysis, i.e., checking normality and trend detection. Kriging is a group of geostatistical techniques to interpolate the value of a random filed (e.g. concentrations of chemical constituent, groundwater level, land elevation, etc. as a function of the geographic locations) at an unobserved location from observation of neighbouring values. The TDS concentration was calculated using the results of the chemical analyses. HT, SAR, per cent sodium $(\% \mathrm{Na})$, residual sodium carbonate (RSC), Kelly's index (KI), permeability index (PI) and magnesium ratio (MR) were also calculated. The PHREEQC-Vr 3, 2013 computer software was used to calculate mineral saturation indices (SI) (Table 2).

\section{Results and discussion}

Understanding the groundwater quality is important as it is the main factor determining its suitability for drinking, domestic, agricultural and industrial purposes (Alam et al. 
Table 2 Summary statistics for physico-chemical and irrigation quality parameters of groundwater with saturation indices (SI) of selected minerals in the study area

\begin{tabular}{|c|c|c|c|c|}
\hline Parameter (units) & Minimum & Maximum & Average & Std. deviation \\
\hline $\mathrm{pH}$ & 7.03 & 7.91 & 7.35 & 0.23 \\
\hline $\mathrm{EC}(\mu \mathrm{S} / \mathrm{cm})$ & 1380 & 14,830 & 5557.76 & 2982.25 \\
\hline TDS (mg/L) & 1133 & 12,460 & 4222.12 & 2475.51 \\
\hline $\mathrm{Na}^{+}(\mathrm{mg} / \mathrm{L})$ & 130 & 1200 & 526.15 & 224.01 \\
\hline $\mathrm{K}^{+}(\mathrm{mg} / \mathrm{L})$ & 2 & 170 & 66.94 & 53.68 \\
\hline $\mathrm{Ca}^{2+}(\mathrm{mg} / \mathrm{L})$ & 60 & 906 & 313.15 & 165.35 \\
\hline $\mathrm{Mg}^{2+}(\mathrm{mg} / \mathrm{L})$ & 31 & 543 & 162.85 & 93.53 \\
\hline $\mathrm{Cl}^{-}(\mathrm{mg} / \mathrm{L})$ & 227 & 2280 & 731.52 & 386.15 \\
\hline $\mathrm{SO}_{4}{ }^{2-}(\mathrm{mg} / \mathrm{L})$ & 307 & 3265 & 1246.64 & 559.66 \\
\hline $\mathrm{HCO}_{3}{ }^{-}(\mathrm{mg} / \mathrm{L})$ & 12 & 1098 & 428.48 & 209.38 \\
\hline $\mathrm{NO}_{3}{ }^{-}(\mathrm{mg} / \mathrm{L})$ & 1.1 & 12 & 4.43 & 2.33 \\
\hline$\% \mathrm{Na}(\%)$ & 27.69 & 73.31 & 43.77 & 5.34 \\
\hline RSBC (meq/L) & -32.44 & 0.9822 & -8.81 & 6.13 \\
\hline SAR (meq/L) & 1.93 & 11.34 & 6.18 & 1.58 \\
\hline PI $(\%)$ & 33.37 & 82.76 & 50.78 & 10.16 \\
\hline $\mathrm{MR}(\mathrm{meq} / \mathrm{L})$ & 37.87 & 56.85 & 46.33 & 3.87 \\
\hline $\mathrm{SI}_{\mathrm{Cal}}$ & -1.81 & 0.86 & 0.1 & 0.42 \\
\hline $\mathrm{SI}_{\text {Dol }}$ & -3.62 & 1.71 & 0.2 & 0.82 \\
\hline $\mathrm{SI}_{\text {Anhy }}$ & -1.56 & -0.13 & -0.73 & 0.29 \\
\hline $\mathrm{SI}_{\text {Arag }}$ & -1.95 & 0.71 & -0.04 & 0.42 \\
\hline $\mathrm{SI}_{\mathrm{Gyp}}$ & -1.32 & 0.11 & -0.5 & 0.29 \\
\hline $\mathrm{SI}_{\mathrm{Hal}}$ & -6.12 & -4.31 & -5.18 & 0.35 \\
\hline
\end{tabular}

$R S B C$ residual sodium bicarbonate, $P I$ permeability index, $S A R$ sodium adsorption ratio, $M R$ magnesium ratio, $S I$ saturation index, Cal calcite, Dol dolomite, Anhy anhydrite, Arg aragonite, Gyp gypsum, Hal halite

2012; Subramani et al. 2005). Table 2 illustrates the physicochemical parameters of groundwater in the Wasit aquifers indicating the minimum, maximum, average and standard deviation values. The physicochemical characteristics of the analytical data and the permissible limits of various organizations such as World Health Organization (WHO 2011) and Iraqi standard (IQS 2009) are presented in Table 3.

\section{Phsicochemical characteristics of groundwater and hydrochemical facies}

The results of the chemical analysis of the groundwater of the area show a wide variation in different individual parameters (Table 2; Fig. 4). The $\mathrm{pH}$ value of groundwater samples ranges from 7.03 to 7.91 with an average value of 7.35 and standard deviation of 0.23 . In general, $\mathrm{pH}$ of the groundwater samples was found to be slightly alkaline in nature.

The electrical conductivity at $25{ }^{\circ} \mathrm{C}$ ranges from 1380 to $14,830 \mu \mathrm{S} / \mathrm{cm}$ with an average of $5557.76 \mu \mathrm{S} / \mathrm{cm}$. The factors responsible for large variation in EC are attributed to geochemical processes such as ionic exchange, reverse exchange, evaporation, silicate weathering, rock-water interaction, sulphate reduction and oxidation processes and anthropogenic activities (Ramesh and Elango 2012). Rao et al. (2002) classified EC as type I, if the enrichments of salts are low $(\mathrm{EC}<1500 \mu \mathrm{S} / \mathrm{cm})$; type II, if the enrichment of salts are medium (EC: 1500 and $3000 \mu \mathrm{S} / \mathrm{cm}$ ); and type III, if the enrichments of salts are high (EC $>3000 \mu \mathrm{S} / \mathrm{cm}$ ), (Prasanth et al. 2012). According to the above classification of EC, the entire groundwater samples come under the type III (high enrichment of salts) except well 42 under type II (medium enrichment of salts). High EC in the study area indicates the high enrichment of salts in the groundwater. Semi-arid climate, high evaporation rate and nutrient enrichment may be responsible for the enrichment of EC.

Water classification based on EC (Table 3) shows that the groundwater samples are slightly $(29.85 \%)$ to moderately $(44.77 \%)$ mineralized water, while 8.95 and $13.43 \%$ of the total groundwater samples are highly mineralized water and excessively mineralized water, respectively. 
Table 3 Water classification based on electrical conductivity (Detay and Carpenter 1997)

\begin{tabular}{llll}
\hline Electrical conductivity $(\mu \mathrm{S} / \mathrm{cm})$ & Mineralization & Number of samples & Percentage of samples \\
\hline$<1000$ & Very weakly mineralized water & - & - \\
$1000-2000$ & Weakly mineralized water & 1 & 1.49 \\
$2000-4000$ & Slightly mineralized water & 20 & 29.85 \\
$4000-6000$ & Moderately mineralized water & 30 & 44.77 \\
$6000-10,000$ & Highly mineralized water & 6 & 8.95 \\
$>10,000$ & Excessively mineralized water & 9 & 13.43 \\
\hline
\end{tabular}

TDS values represent the concentration of a solution in terms of the total weight of dissolved solids, which in turn reflects the degree of salinity (Mitra et al. 2007). To ascertain the suitability of groundwater for any purpose, it is essential to classify the groundwater depending upon its hydrochemical properties based on the TDS values (Todd 2009), Table 4. The TDS values of groundwater samples varied considerably, with the highest of $12,460.0 \mathrm{mg} / \mathrm{L}$ observed in sample $\mathrm{W} 5$, followed by $11,400.0$ and $9630 \mathrm{mg} / \mathrm{L}$ in $\mathrm{W} 37$ and W41, respectively. The lowest TDS value $(1133 \mathrm{mg} / \mathrm{L})$ was observed in sample W42. The mean value of TDS was $4222.12 \mathrm{mg} /$ L. High concentration of TDS in the groundwater sample is due to leaching of salts from aquifer matrix and domestic sewage that may percolate into the groundwater (Prasanth et al. 2012). According to the classification of groundwater based on TDS, (Table 4), the all groundwater samples fall in slightly brackish water class except two samples (W5 and W37) which are characterized as saline water class. Spatial distributions of EC and TDS and other parameters are presented in maps (Figs. 5, 6 and 7). These maps showed that the concentrations are higher in the northern part of the study area comparing to the other areas.
The concentrations of potassium range from 2 to $170.0 \mathrm{mg} / \mathrm{L}$ with an average value of $66.94 \mathrm{mg} / \mathrm{L}$. The higher concentration of potassium in groundwater is due to the anthropogenic sources and saline intrusion.

The concentrations of $\mathrm{Na}^{+}$varied from 130 to $1200 \mathrm{mg} /$ $\mathrm{L}$ with an average of 526.15. The maximum permissible limit of sodium is $200 \mathrm{mg} / \mathrm{L}$. The high concentration of $\mathrm{Na}^{+}$is as a result of weathering of rock-forming minerals such as halite and sodium plagioclase, along with anthropogenic sources including industrial, domestic and animal wastes (Freeze and Cherry 1979).

$\mathrm{Ca}^{2+}$ concentrations varied from 60 to $906 \mathrm{mg} / \mathrm{L}$ with an average value of 313.15 (Table 2). $\mathrm{Ca}^{2+}$ can be derived from dissolution of carbonate and evaporitic minerals (e.g., calcite, dolomite, aragonite, gypsum and anhydrite) as well as carbonate cement within formations (Bozdağ and Göçmez 2013).

Magnesium content varied from 31 to $543 \mathrm{mg} / \mathrm{L}$ with an average value of $162.85 \mathrm{mg} / \mathrm{L}$ (Table 2). The concentration of $\mathrm{Ca}$ and $\mathrm{Mg}$ in the groundwater is most probably derived from leaching of carbonate minerals such as calcite and dolomite (Magesh et al. 2013). Spatial distributions of cations are presented in maps (Fig. 6). These maps showed that the concentrations are higher in the northern and southeastern part of the study area comparing to the other areas.

Table 4 Classification of groundwater according to the TDS (mg/L)

\begin{tabular}{|c|c|c|c|c|}
\hline & TDS & Water class & Number of samples & Percentage of samples \\
\hline \multirow[t]{5}{*}{ According to Freeze and Cherry (1979) } & $<1000$ & Fresh water type & - & \\
\hline & $1000-10,000$ & Brackish water type & 65 & 97.02 \\
\hline & $10,000-100,000$ & Saline water type & 2 & 2.98 \\
\hline & $>100,000$ & Brine water type & - & - \\
\hline & Total & & 67 & 100 \\
\hline \multirow[t]{5}{*}{ According to Todd (2009) } & $10-1000$ & Fresh water & - & \\
\hline & $1000-10,000$ & Slightly-Brackish water & 65 & 97.02 \\
\hline & $10,000-100,000$ & Brackish water & 2 & 2.98 \\
\hline & $>100,000$ & Brine water & - & - \\
\hline & Total & & 67 & 100 \\
\hline
\end{tabular}



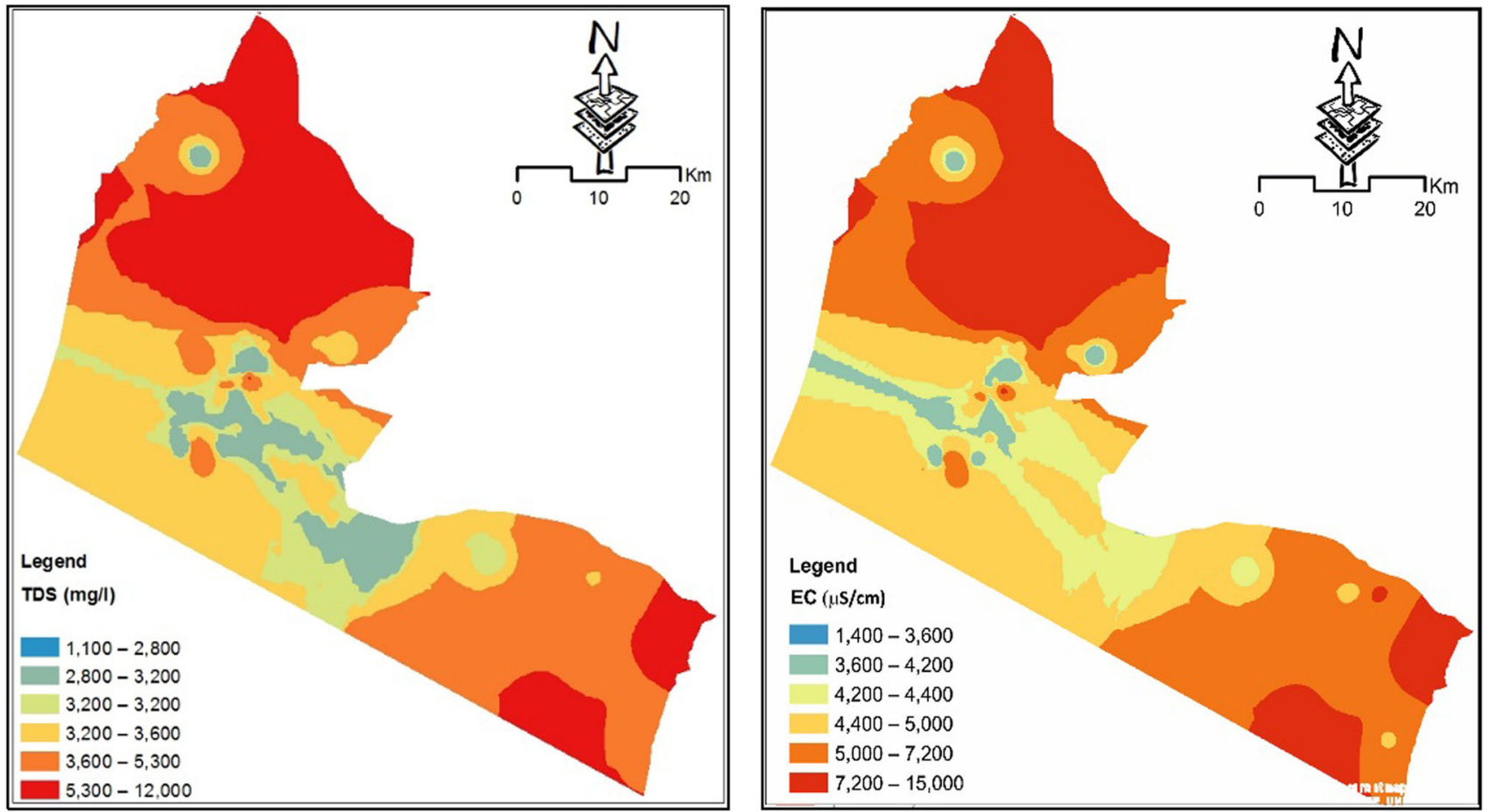

Fig. 5 Distribution pattern of electrical conductivity $(\mu \mathrm{S} / \mathrm{cm})$ and total dissolved solids (TDS-mg/L)

The chloride concentration varies between 227 and $2280 \mathrm{mg} / \mathrm{L}$ with an average value of $731.52 \mathrm{mg} / \mathrm{L}$. The higher concentrations of chloride in the groundwater may be attributed to the percolation of domestic sewage and irrigated land water (Fig. 7) (Bhatia 2003).

The sulphate concentrations in the study area range from 307 to $3265 \mathrm{mg} / \mathrm{L}$ with an average value of $3265 \mathrm{mg} / \mathrm{L}$ (Table 2) (Fig. 7). The possible source of sulphates is from gypsum-bearing carbonate sedimentary rocks. Higher sulphate content may have a laxative effect with excess of magnesium and also causes corrosion of metals in the distribution system if the water had low alkaline (Raju et al. 2011).

The value of bicarbonate is observed from 12 to $1098 \mathrm{mg} / \mathrm{L}$ with an average value of $428.48 \mathrm{mg} / \mathrm{L}$ (Table 2). The higher concentration of $\mathrm{HCO}_{3}{ }^{-}$in the groundwater points indicate to the dominance of mineral dissolution (Stumm and Morgan 2012).

Finally, the value of $\mathrm{NO}_{3}{ }^{-}$ranged between 0.9 and $15.63 \mathrm{ppm}$. The most important source of $\mathrm{NO}_{3}{ }^{-}$is the biological oxidation of nitrogenous substances which come in sewage and industrial wastes or produced naturally from waste. The geological, atmospheric precipitation and agriculture are the major sources of $\mathrm{NO}_{3}{ }^{-}$. The variables which control the reaction of phosphate in soil are the solubility of fertilizers, the inorganic or organic form, soil $\mathrm{pH}$, presence of calcareous materials and water management practices (Ranjan et al. 2013).
Hydrochemical concepts can help to elucidate mechanisms of flow and transport in groundwater systems and unlock an archive of paleo environmental information (Hem 1985; Ophori and Toth 1989). Piper plot (Piper 1944) is used to infer hydrogeochemical facies of groundwater. Geochemical graphic analyses methods, especially Piper diagram (Piper 1944), have been widely used in groundwater studies to characterize a large number of water chemical data. This diagram reveals similarities and differences among groundwater samples because those with similar qualities will tend to plot together as groups (Todd 2009). For plotting Piper diagram, the Schlumberger water services AquaChem software version 2012.1.123 software is used to display the relative concentrations of the different ions from individual water samples from the study area. The piper's trilinear diagram showing chemical relationship of groundwater constituents from studied area is given in Fig. 8. From the cationic and anionic triangular field of Piper diagram, it is observed that most of water samples fall in the zone of no dominant cation and anion type $(67.16 \%)$, and $32.83 \%$ of water samples falls in zone of $\mathrm{Na}+$ sodium type. From predominate anion it is clear that the sulphates and chloride exceed the other anion (Fig. 8). Three hydrogeochemical type facies were identified from different aquifers occurring in the study area. Majority of the samples belong to the Mixed $\mathrm{CaMgCl}$ (47.76\%) followed by the $\mathrm{Na}^{+}-\mathrm{Cl}^{-}-\mathrm{SO}_{4}{ }^{2-}$ type $(26.86 \%$ ) 

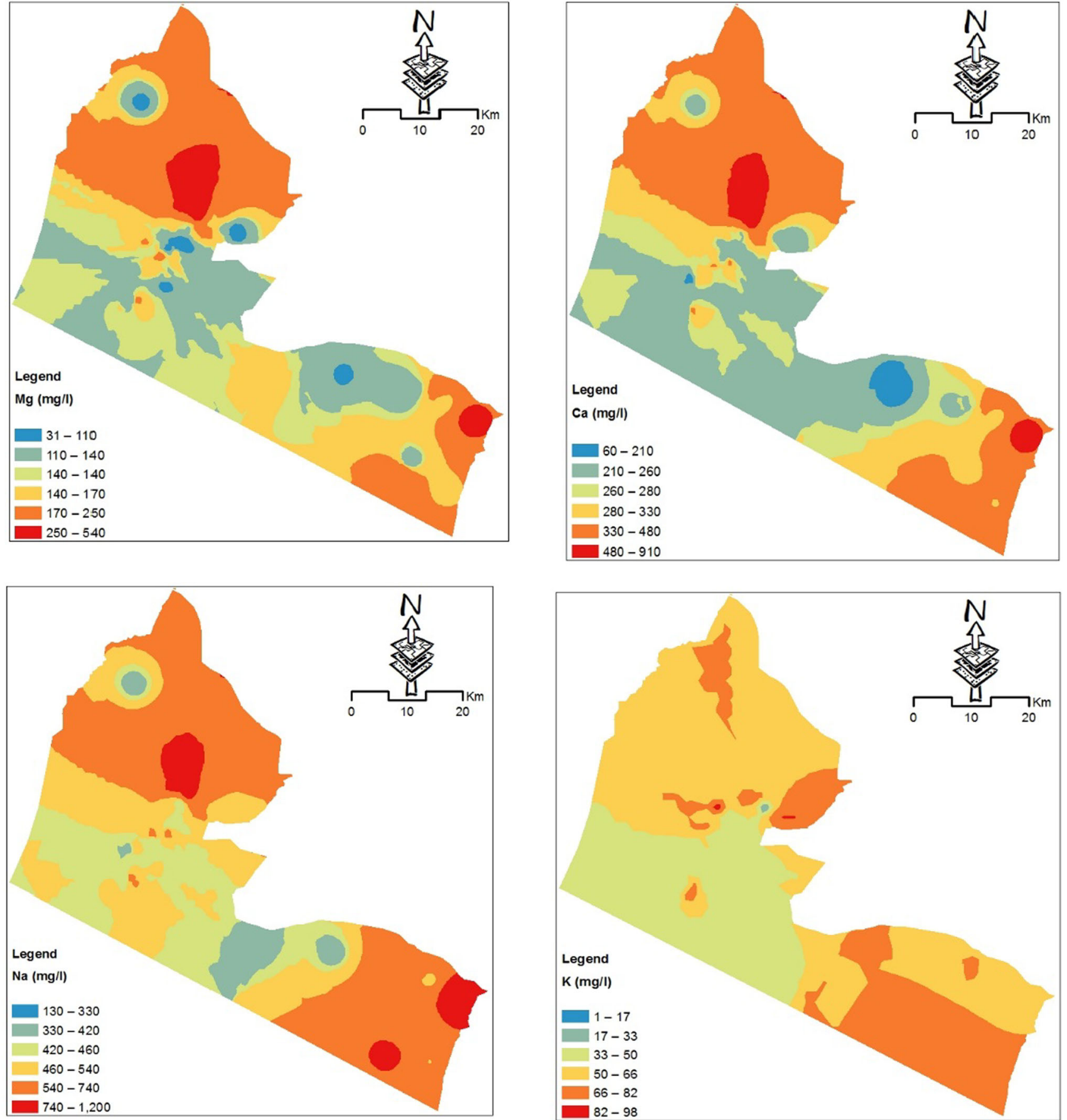

Fig. 6 Spatial distribution pattern of cations $\left(\mathrm{Ca}^{2+}, \mathrm{Mg}^{2+}, \mathrm{Na}^{+}\right.$and $\left.\mathrm{K}^{+}\right)(\mathrm{mg} / \mathrm{L})$

and $\mathrm{Ca}^{2+}-\mathrm{Mg}^{2+}-\mathrm{Cl}^{-}-\mathrm{SO}_{4}{ }^{2-}(25.37 \%)$ types in the study area (Table 5).

Water types $(\mathrm{CaMgCl}, \mathrm{NaCl}$ and $\mathrm{CaCl})$ suggest the dissolution of rock-forming minerals like halite and carbonatebearing minerals, domestic waste water, ion exchange process and the great effects of the evaporates dispersed in the aquifer matrix. In general, alkalis $(\mathrm{Na}+\mathrm{K})$ are significantly dominating over the alkali earth elements $\left(\mathrm{Ca}^{2+}+-\right.$ $\left.\mathrm{Mg}^{2+}\right)$, and strong acids $\left(\mathrm{Cl}^{-}\right.$and $\left.\mathrm{SO}_{4}{ }^{2-}\right)$ dominate over weak acid $\left(\mathrm{CO}_{3}\right.$ and $\left.\mathrm{HCO}_{3}{ }^{-}\right)$in most of the samples. 

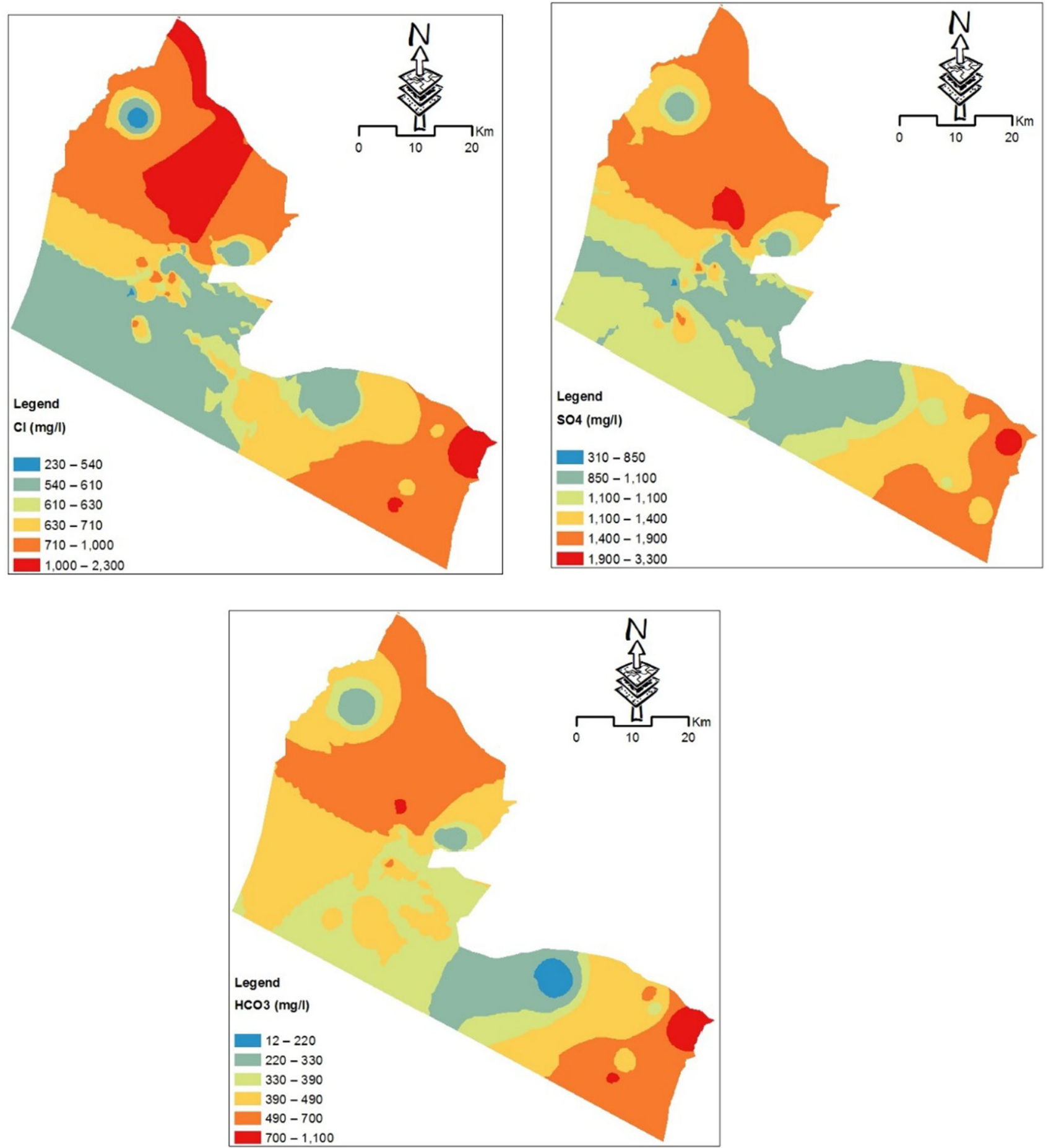

Fig. 7 Spatial distribution pattern of anions $\left(\mathrm{Cl}^{-}, \mathrm{SO}_{4}{ }^{2-}, \mathrm{HCO}_{3}{ }^{-}\right)(\mathrm{mg} / \mathrm{L})$

\section{Geochemical evolution of Wasit aquifer water}

The Durov's diagram (Durov 1948), helps the interpretation of the evolutionary trends and the hydrochemical processes occurring in the groundwater system and can indicate mixing of different water types, ion exchange and reverse ion exchange processes. Lloyd and Heathcote
(1985) defined nine regions in the central rectangle, and the significance of each is as follows: region $1\left(\mathrm{HCO}_{3}{ }^{-}\right.$ and $\mathrm{Ca}^{2+}$ dominated) frequently indicates recharging waters in limestones, sandstones, and many other aquifers; region $2\left(\mathrm{HCO}_{3}{ }^{-}\right.$and $\mathrm{Mg}^{2+}$ or $\mathrm{Ca} / \mathrm{Na}$ indiscriminate $)$ and region $3\left(\mathrm{HCO}_{3}{ }^{-}\right.$and $\mathrm{Na}$ dominant) indicate ion-exchange waters; regions 4 and 5 indicate waters exhibiting 
Fig. 8 Piper (1944) diagram of groundwater samples of the present study

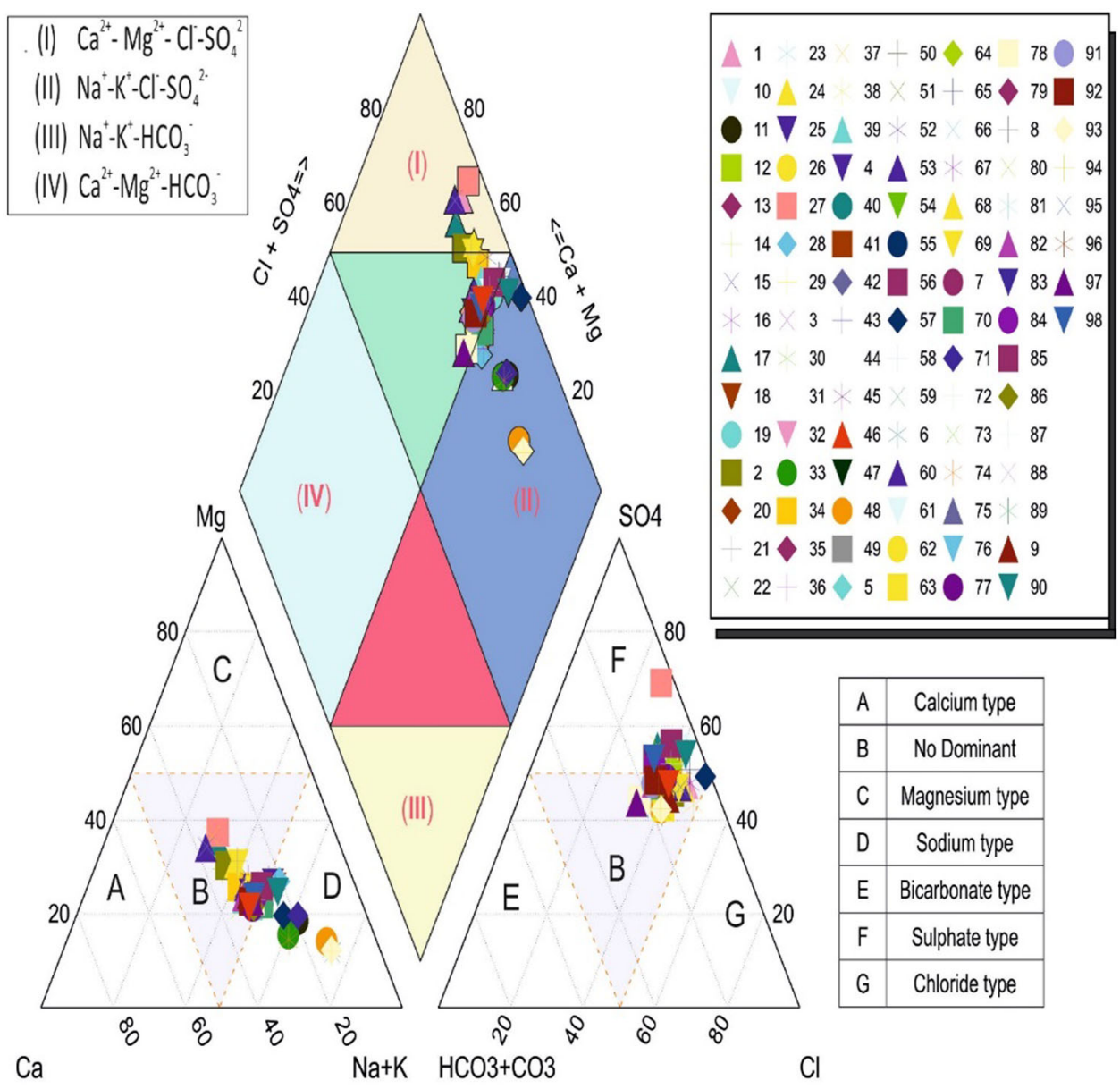

\begin{tabular}{|l|l|l|l|l|l|}
\hline & & & & & \\
\hline $\mathrm{CaHC03}$ & $\mathrm{NaCl}$ & Mixed $\mathrm{CaNaHCO}_{3}$ & Mixed $\mathrm{CaMgCl}$ & $\mathrm{CaCl}$ & $\mathrm{NaHCO}_{3}$ \\
\hline
\end{tabular}

Table 5 Hydrochemical facies of groundwater samples into different water types in the study area

\begin{tabular}{llll}
\hline Facies type & Mixed $\mathrm{CaMgCl}$ & $\mathrm{Na}^{+}-\mathrm{Cl}^{-}-\mathrm{SO}_{4}{ }^{2-}$ & $\mathrm{Ca}^{2+}-\mathrm{Mg}^{2+}-\mathrm{Cl}^{-}-\mathrm{SO}_{4}{ }^{2-}$ \\
\hline Percentage & 47.76 & 26.86 & 25.37 \\
\hline
\end{tabular}

simple dissolution or mixing; region 6 indicates a probable mixing influence; regions 7 and 8 indicate reverse ion-exchange reactions; and region 9 represents end point waters. Chemical data of groundwater samples of study area have been plotted on the Durov diagram (Fig. 9). The results of plotted chemical data on Durov's diagram is used to identify the geochemical evolution of groundwater where the groundwater is initially recharged by $\mathrm{Ca}-$ $\mathrm{HCO}_{3}$ water (rain water) and undergo water-rock interactions (dissolution) and mixing with pre-existing groundwater in karstified dolomitic limestone that may be of saline nature. This leads to the evolution of $\mathrm{Mg}-\mathrm{SO}_{4}$ and $\mathrm{Na}_{2} \mathrm{SO}_{4}$ water types and finally reaches an advanced state of geochemical evolution, which is represented by the $\mathrm{Na}-\mathrm{Cl}$ type. According to Durov's diagram, most of the groundwater samples $(82.7 \%)$ are all in zone 5 that represented by $\mathrm{Ca}-\mathrm{Mg}-\mathrm{HCO}_{3}-\mathrm{SO}_{4}$ water type, indicating mixed water type that affected by dissolution process. This water is possibly evolved from $\mathrm{Ca}-\mathrm{HCO}_{3}$ recharge water and may effected by ion exchange process (presence of $\mathrm{Na}_{2} \mathrm{SO}_{4}$ water type in field No. 6). In addition to this, few samples $(7.0 \%)$ showing reverse ion exchange have been noticed in zone No. 8 (presence of $\mathrm{MgCl}_{2}$ water type). 


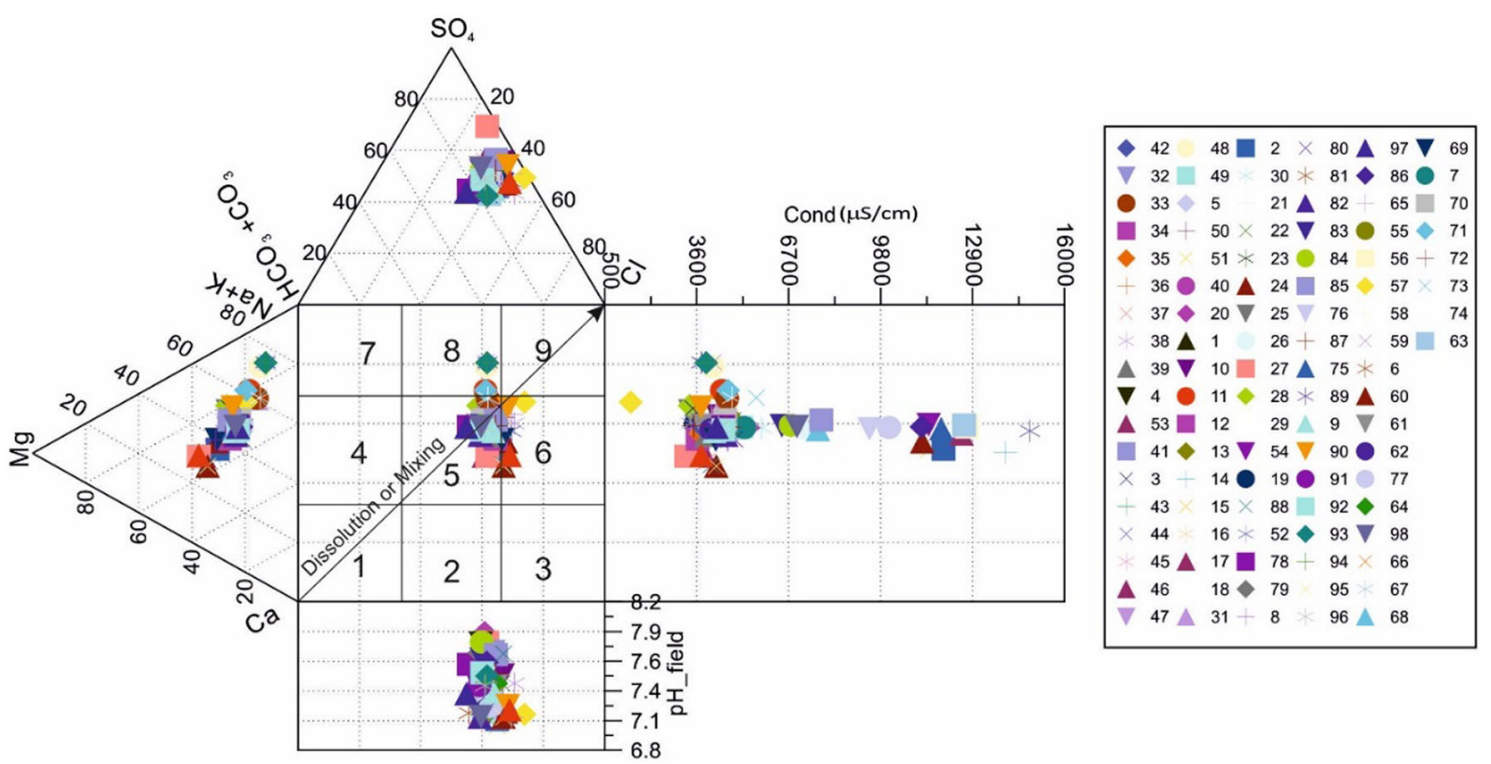

Fig. 9 Chemical facies of groundwater in Durov diagram of the present study

\section{Chemical equilibrium saturation}

The quality of the recharge waters and its interactions with soil and rocks during its percolation and its storage in the aquifers are key factors in the chemistry of groundwater (Ghalib and Söğü 2014). These interactions involve mainly dissolution and precipitation processes, which are controlled by the solubility products of different mineral phases involved. Generally, the saturation indices (SI) are used to expresses the tendency of water towards precipitation or dissolution. The saturation state for a given a mineral is expressed as saturation index (SI), as given by Lee (1993):

$\mathrm{SI}=\log \operatorname{IAP} / K(t)$,

where IAP $=$ ionic activity product $K(t)=$ mineral equilibrium constant when SI $>0$, the specific mineral is oversaturated and precipitation is possible; when $\mathrm{SI}=0$, the specific mineral is in equilibrium with the solution and when SI $<0$, the specific mineral is undersaturated and dissolution is possible. The geochemical modelling program PHREEQC v3 (Parkhurst and Appelo 2013) was used to calculate saturation indices at the field temperature and the thermodynamic equilibrium conditions of waters with respect to the main mineral phases, evaporate (gypsum, anhydrite and halite) and carbonate (calcite, dolomite and aragonite) present in the aquifer. From the results of geochemical modelling in the course of groundwater evolution, significant relationship between $\mathrm{SO}_{4}$ and S.I of the selected minerals were observed (Fig. 10). For carbonate minerals, as $\mathrm{SO}_{4}$ concentration increases, the Calcite and Dolomite SIs increase and exceed the equilibrium limit,

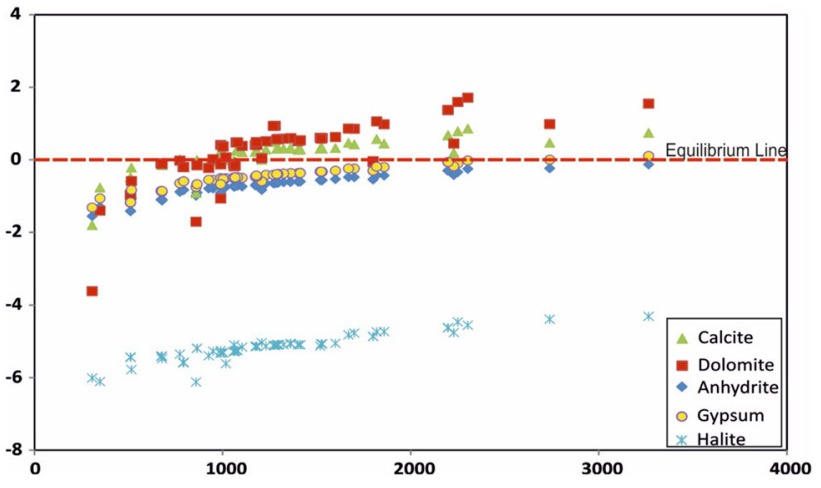

Fig. 10 Plot of saturation indices with respect to carbonate and evaporate minerals against TDS

whereas for sulphate minerals, the increase of $\mathrm{SO}_{4}$ concentration leads to less proportional increase of S.I, but never exceeds equilibrium limit. General decrease in S.Is of these minerals along the flow direction was also observed. SI values of halite vary between -6.12 and -4.31 with an average value of -5.18 (Fig. 10). These results suggest that the precipitation of the carbonate is highly affected by the dissolution of evaporate minerals.

\section{Processes controlling the groundwater chemistry}

The reaction between groundwater and aquifer minerals plays a significant role in water quality, which is also useful in understanding the genesis of groundwater (Bozdag and Göçmez 2013). Gibbs (1970) has suggested a diagram wherein the ratio of dominant cations $[(\mathrm{Na}+\mathrm{K}) /$ $(\mathrm{Na}+\mathrm{K}+\mathrm{Ca})]$ and cations anions $\left[\mathrm{Cl} . /\left(\mathrm{Cl}+\mathrm{HCO}_{3}\right)\right]$ 
was separately plotted against the TDS (Fig. 11). Hence, Gibbs plot is employed in this study to understand the functional sources of dissolved chemical constituents in groundwater from their respective aquifers such as chemistry of the rock types (rock dominance), chemistry of precipitated water (precipitation dominance) and rate of evaporation (evaporation dominance). Figure 11 clearly shows that all of the groundwater samples fall in the evaporation zone which suggests that the evaporation process primarily controls the major ion chemistry of groundwater in this region. The climate of the Wasit region is semi-arid; hence, groundwater evaporation is a prevalent phenomenon. Evaporation increases salinity by increasing $\mathrm{Na}$ and $\mathrm{Cl}$ content and, therefore, increasing these ions is derived from the weathering of magnesium and sodium sulphate minerals (Esmaeili and Moore 2012).

Figure 11. Gibbs diagram for controlling factor of groundwater quality in the study area

\section{Drinking water quality}

The spatial distributions of groundwater quality parameters were estimated using Geostatistical module of ArcGIS 10.4.1TM. The inverse distance weighted (IDW) interpolation technique was used for interpolating the parameter

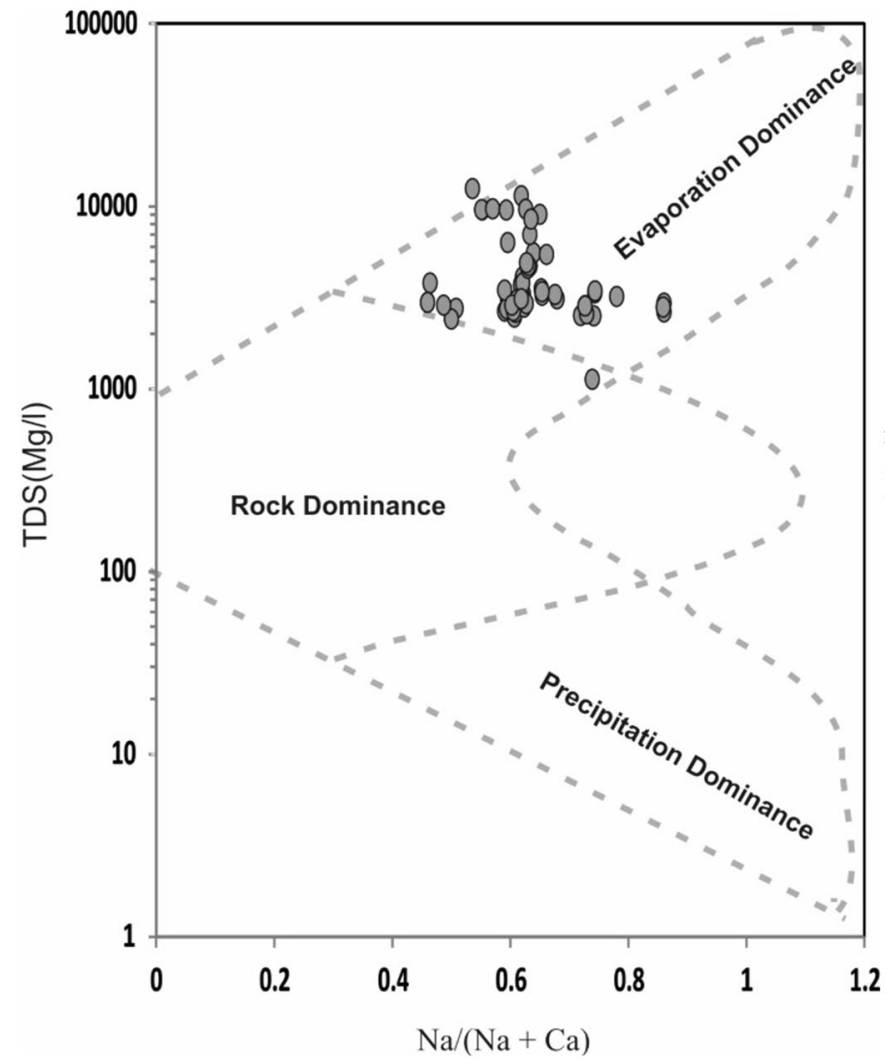

values and finally the resultant interpolated values were classified according to the WHO (2011) and IQS (IQS 2009) standards for drinking water. Table 6 shows the hydrochemical parameters of the study area in comparison with above drinking water standards. In general, $\mathrm{pH}$ of the groundwater samples was found to be slightly alkaline in nature and within the permissible limit suggested by WHO and IQS. The General Commission of Iraqi and World Health Organization Standards has recommended $1000 \mathrm{mg} / \mathrm{L}$ as the maximum permissible limit for TDS in drinking water (Table 6). The spatial variation map of TDS was prepared based on these standards and presented in (Fig. 12). From the spatial variation map, it was observed that in most of the area, the TDS value is in the medium range $(1133-1500 \mathrm{mg} / \mathrm{L})$. From these and previous results, all selected groundwater samples were found to be unsuitable for drinking purposes (Table 6) and (Fig. 12).

\section{Irrigation water quality assessment}

The suitability of groundwater for agricultural purposes depends on the effect of mineral constituents of water on both plants and soil. The chemical effects disrupt plant metabolism, while the physical effects lower permeability in soil and

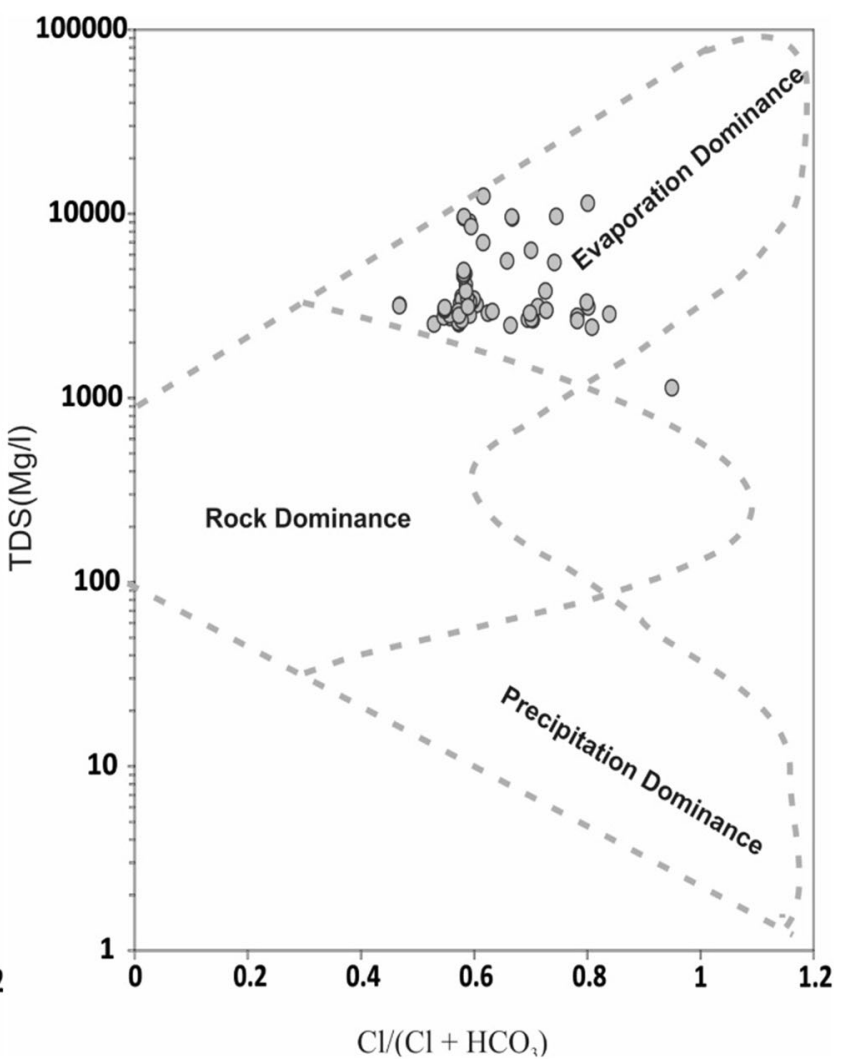

Fig. 11 Gibbs diagram for controlling factor of groundwater quality in the study area 
Table 6 The hydrochemical parameters of the study area in comparison with WHO (2011) and IQS 2009 drinking water Standards

\begin{tabular}{|c|c|c|c|c|c|}
\hline Parameters (units) & $\begin{array}{l}\text { WHO (2011) } \\
\text { ppm }\end{array}$ & $\begin{array}{l}\text { IQS (2009) } \\
\text { ppm }\end{array}$ & $\begin{array}{l}\text { Number of samples } \\
\text { exceeding desirable } \\
\text { limits }\end{array}$ & $\begin{array}{l}\text { Percentage of } \\
\text { samples }\end{array}$ & Well number \\
\hline $\mathrm{pH}$ & $6.5-8.5$ & $6.5-8.5$ & - & - & - \\
\hline $\mathrm{Ca}^{2+}(\mathrm{mg} / \mathrm{L})$ & 75 & 150 & 85 & 86.73 & $\begin{array}{l}\text { All the numbers except }(1,10,18,20,21,23,30 \text {, } \\
\quad 43,53,55,88,93,94)\end{array}$ \\
\hline $\mathrm{Mg}^{2+}(\mathrm{mg} / \mathrm{L})$ & 100 & 100 & 80 & 81.63 & $\begin{array}{l}\text { All the numbers except }(1,10,16,18,20 \text {, } \\
23,25,27,30,43,53,55,71,72,79,88,93,94)\end{array}$ \\
\hline $\mathrm{Na}^{+}(\mathrm{mg} / \mathrm{L})$ & 200 & 200 & 95 & 96.93 & $1,20,53$ \\
\hline $\mathrm{K}^{+}(\mathrm{mg} / \mathrm{L})$ & 10 & - & 77 & 78.57 & $\begin{array}{l}\text { All the numbers except }(7,9,10,12,15,16 \text {, } \\
\quad \begin{array}{l}18,21,23,25,26,27,30,31,53,66,71,72,78, \\
79,89)\end{array}\end{array}$ \\
\hline $\mathrm{Cl}^{-}(\mathrm{mg} / \mathrm{L})$ & 250 & 350 & 94 & 95.91 & $1,20,53,79$ \\
\hline $\mathrm{SO}_{4}{ }^{2-}(\mathrm{mg} / \mathrm{L})$ & 250 & 400 & 96 & 97.95 & 1,53 \\
\hline $\mathrm{NO}_{3}{ }^{-}(\mathrm{mg} / \mathrm{L})$ & 50 & 50 & - & - & - \\
\hline TDS (mg/L) & 1000 & 1000 & 68 & 100 & - \\
\hline
\end{tabular}

reduce osmotic pressure in the plant cell structure, therefore, preventing water from reaching branches and leaves (Sahinci 1991). Therefore, it is necessary to know the quality of the groundwater for irrigation purposes. For determining the irrigation water quality in the study area, some important hydrochemical parameters such as EC, salinity, percent sodium, sodium adsorption ratio (SAR), sodium ratio $(\% \mathrm{Na})$, residual sodium carbonate (RSC), permeability index (PI) and magnesium ratio (MR) are used.

\section{Sodium adsorption ratio (SAR)}

Sodium adsorption ratio (SAR) is a measure of the suitability of water for use in agricultural irrigation, because sodium concentration can reduce the soil permeability and soil structure (Todd 2009). Salinity indicates leaching of salts into groundwater. This creates a lot of problems, especially in dry climatic regions, where clayey soils occur. As the water salinity develops saline soils, this in turn affects the salt intake capacity of plants through the roots. Excess concentration of salts in agricultural fields due to loss of water through evaporation causes poor drainage conditions. These conditions decline groundwater levels up to the root zone of plants, which accumulates the salts in soil solution through capillary rise, following the water evaporation (Hem 1985). The SAR measures the relative proportion of sodium ions in a water sample to those of calcium and magnesium (Kalra and Maynard 1991) and is calculated using the following equation:

$\mathbf{S A R}=\frac{\mathbf{N a}^{+}}{\sqrt{\left(\mathbf{C a}^{2+}+\mathbf{M g}^{2+}\right) / 2}}$ where the concentrations are reported in meq/L.

The calculated values of SAR in the study area vary between 1.93 and 11.34 with an average 6.18 (Table 2). SAR values are high, indicating precipitation-induced dissolution and leaching of salts. For rating irrigation waters the United States salinity diagram (Wilcox 1948) was obtained by plotting the correlation between SAR and electrical conductivity (Fig. 12). The USSL plot indicates that majority of the groundwater samples $(52.23 \%)$ fall within the $\mathrm{C}_{4}-\mathrm{S}_{2}$ category indicating very high salinitymedium sodium water type. About $32.83 \%, 8.95$ and 4.47 of the groundwater samples fall in the $\mathrm{C}_{4}-\mathrm{S}_{3}, \mathrm{C}_{4}-\mathrm{S}_{1}$ and $\mathrm{C}_{4}-\mathrm{S}_{4}$ classes indicating very high salinity-high sodium, very high salinity-low sodium, very high salinity-very high sodium types of water, respectively (Fig. 13). Only $1.49 \%$ (representative only one sample) falls in the $\mathrm{C}_{3}-\mathrm{S}_{1}$ zone indicating high salinity-low sodium hazard class (Fig. 12). Groundwater that falls within the $\mathrm{C}_{4}-\mathrm{S}_{2}, \mathrm{C}_{4}-\mathrm{S}_{3}$, $\mathrm{C}_{4}-\mathrm{S}_{4}$ and $\mathrm{C}_{4}-\mathrm{S}_{1}$ cannot be used for irrigation in almost all types of soil except those having high permeability (Kumar et al. 2007), whereas $C_{3}-S_{1}$ type of water could only be used to irrigate certain semi-tolerant crops (Salifu et al. 2015). United States salinity diagram (Wilcox 1948) was obtained by plotting the correlation between SAR and electrical conductivity (Fig. 12).

\section{Sodium percentage $(\% \mathrm{Na})$}

Sodium percentage is an important parameter for studying sodium hazard. Sodium content and specific conductivities of the waters are important parameters that control the usage of water in agriculture. The presence of $\mathrm{Na}+$ in irrigational 

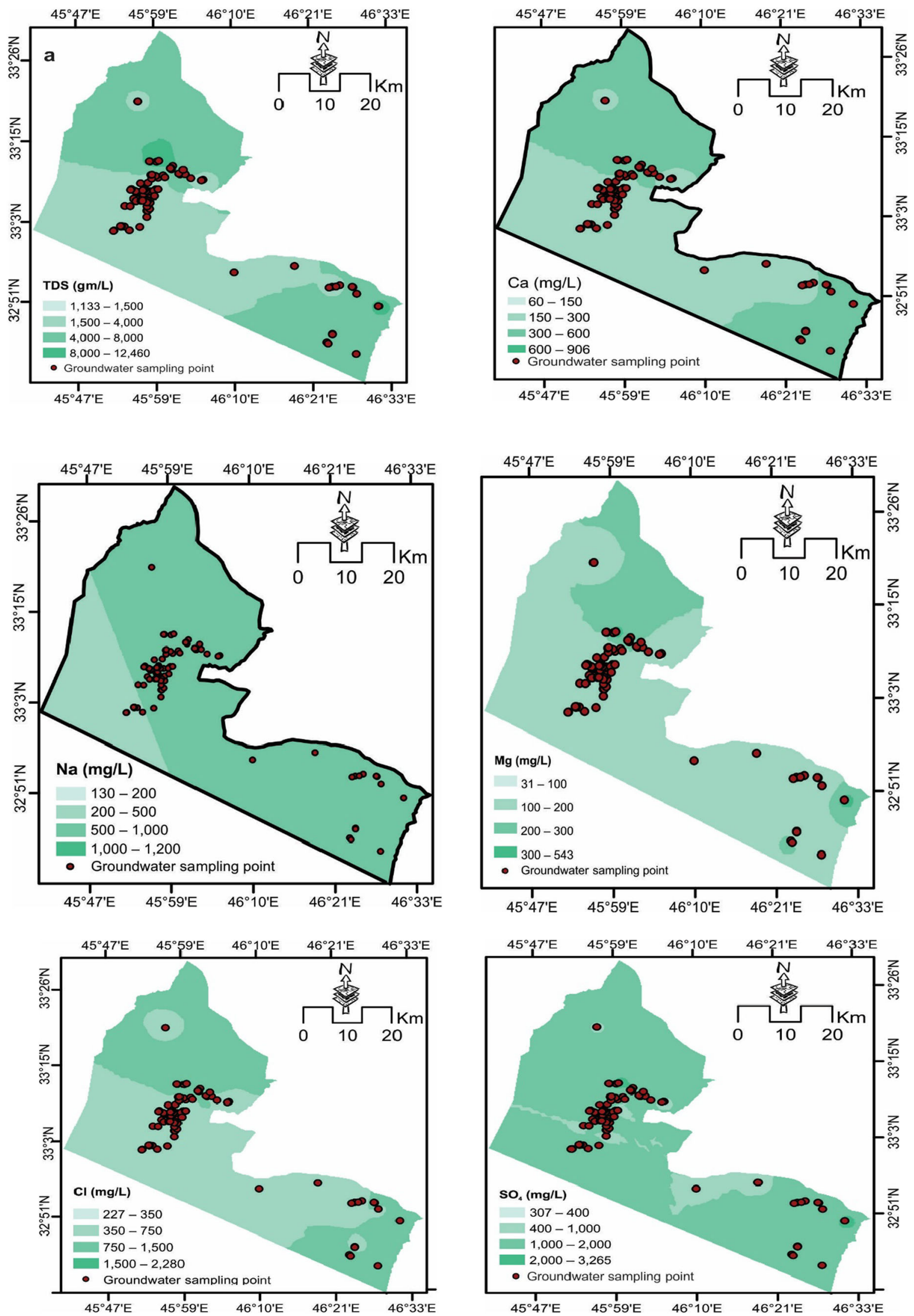

Fig. 12 The water quality zones to drink water quality for study area 


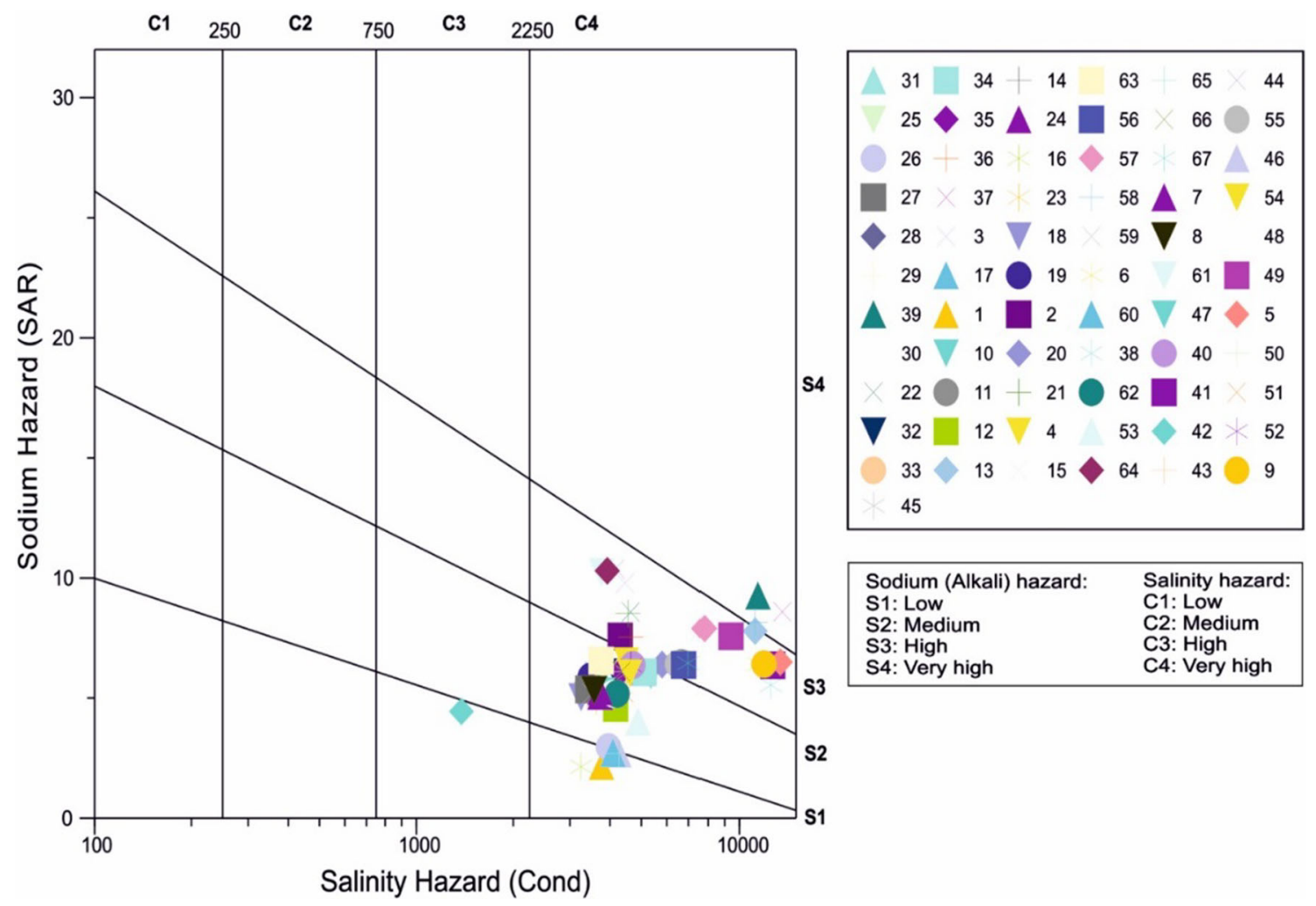

Fig. 13 Plot of classification of irrigation water quality, with respect to salinity hazard and sodium hazard percent sodium (\%Na)

water decreases the soil permeability (Raju 2007). The per cent sodium $(\% \mathrm{Na})$ is widely used for evaluating the suitability of water quality for irrigation (Wilcox 1955). $\mathrm{Na} \%$ is calculated using the following formula and all concentrations were expressed in meq/L (Wilcox 1955):

$\% \mathrm{Na}=\mathrm{Na}^{+} \times 100 /\left[\mathrm{Ca}^{2+}+\mathrm{Mg}^{2+}+\mathrm{Na}^{+}+\mathrm{K}^{+}\right]$,

where $\% \mathrm{Na}$ ranges from 27.69 to $73.31 \%$ with an average $43.77 \%$ in the studied area. The plot of the Wilcox diagram shows that all samples fall under unsuitable category except one sample that falls in the field of permissible to doubtful for irrigation as shown in the Fig. 14. The presence of excess of sodium causes most of the samples to be in the permissible-todoubtful ranges and restricts air and water circulation in the soil during wet conditions (Collins and Jenkins 1996; Saleh et al. 1999). In the study area, the agricultural yields are observed to be generally low in lands irrigated with waters belonging in the doubtful to unsuitable and unsuitable categories. This is probably due to the presence of sodium salts, which causes osmotic effects in soil plant system (Bozdağ 2015).

\section{Residual sodium bicarbonate}

Gupta and Gupta (1987) classified water on the basis of "RSBC". RSBC was calculated for each well by equation given by Gupta and Gupta (1987).

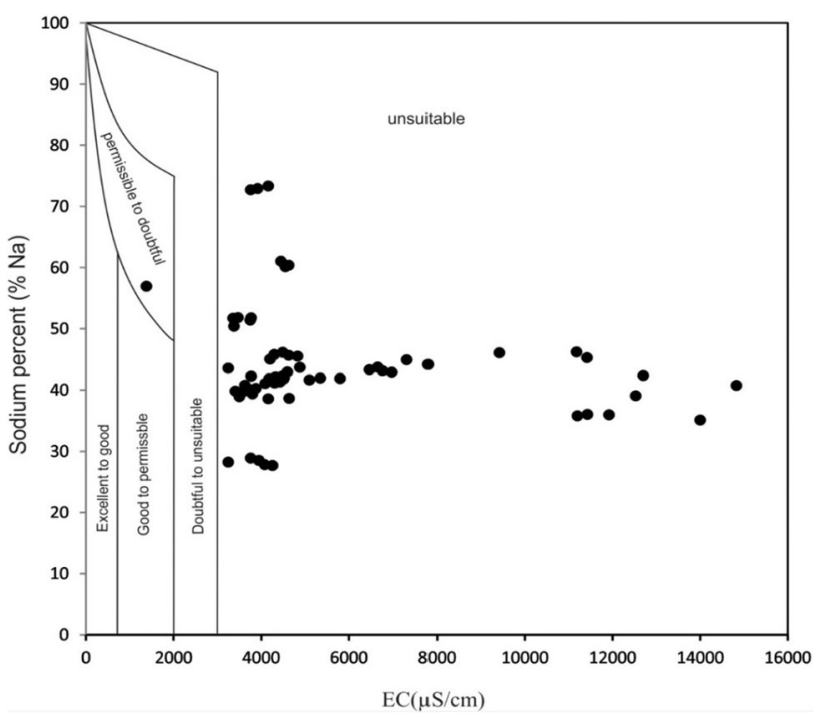

Fig. 14 Plot of classification of irrigation waters (after Wilcox 1955)

$\mathrm{RSBC}=\left(\mathrm{HCO}_{3}-\mathrm{Ca}\right)$

The RSBC was classified into satisfactory $(<5 \mathrm{meq} / \mathrm{L})$, marginal $(5-10 \mathrm{meq} / \mathrm{L})$ and unsatisfactory $(>10 \mathrm{meq} / \mathrm{L})$. The calculated values of "RSBC" are presented in Table 2 for the groundwater in the study area. The RSBC of groundwater ranged from -32.66 to $0.98 \mathrm{meq} / \mathrm{L}$ with an average value of $-9.81 \mathrm{meq} / \mathrm{L}$ (Table 2). According to the 
RSBC values, all groundwater samples collected were found to be satisfactory $(<5 \mathrm{meq} / \mathrm{L})$ according to the criteria set by Gupta and Gupta (1987). The RSBC values are $<5 \mathrm{meq} / \mathrm{L}$ and are, therefore, considered safe for irrigation purposes.
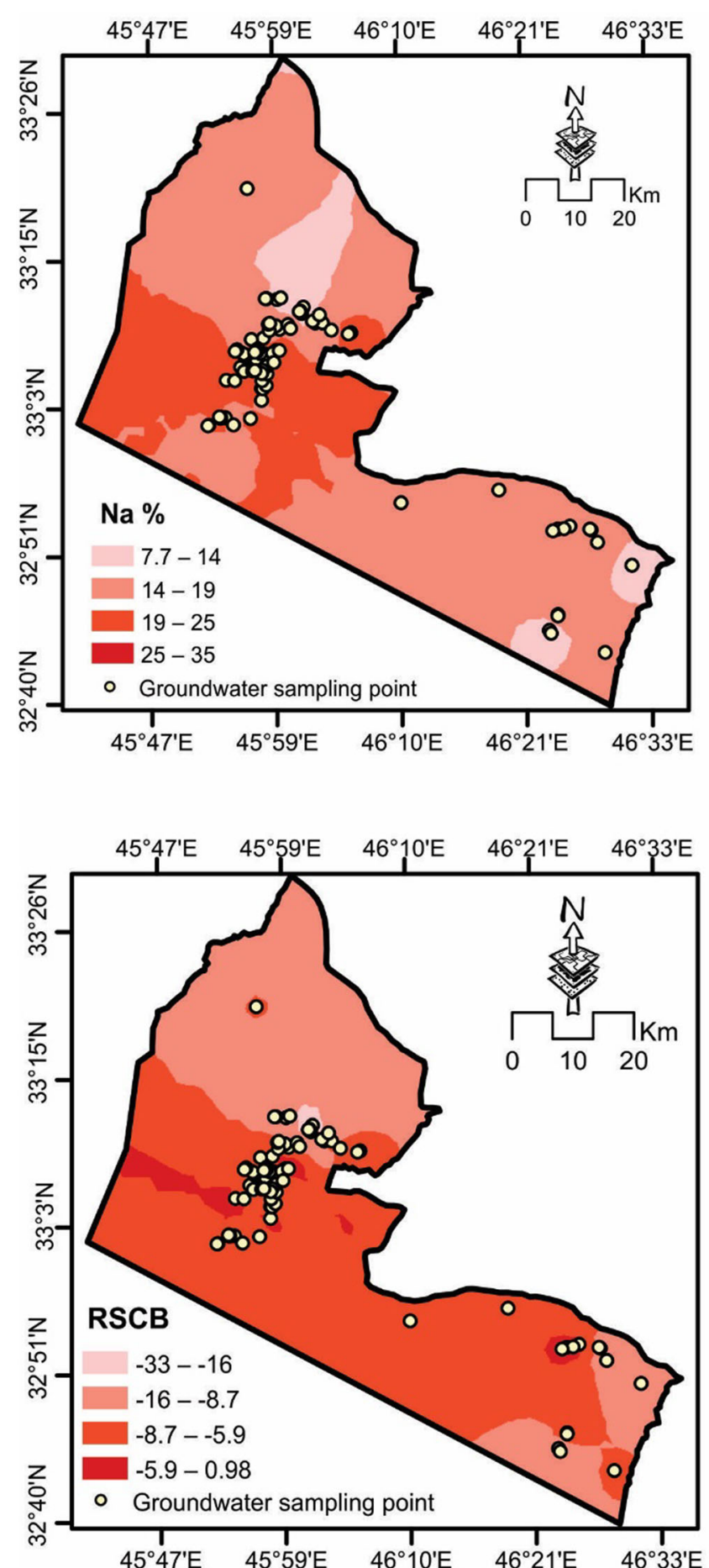

\section{Permeability index (PI)}

The permeability index also indicates whether groundwater is suitable for irrigation. The soil permeability is affected by the long-term use of irrigation water as influenced by
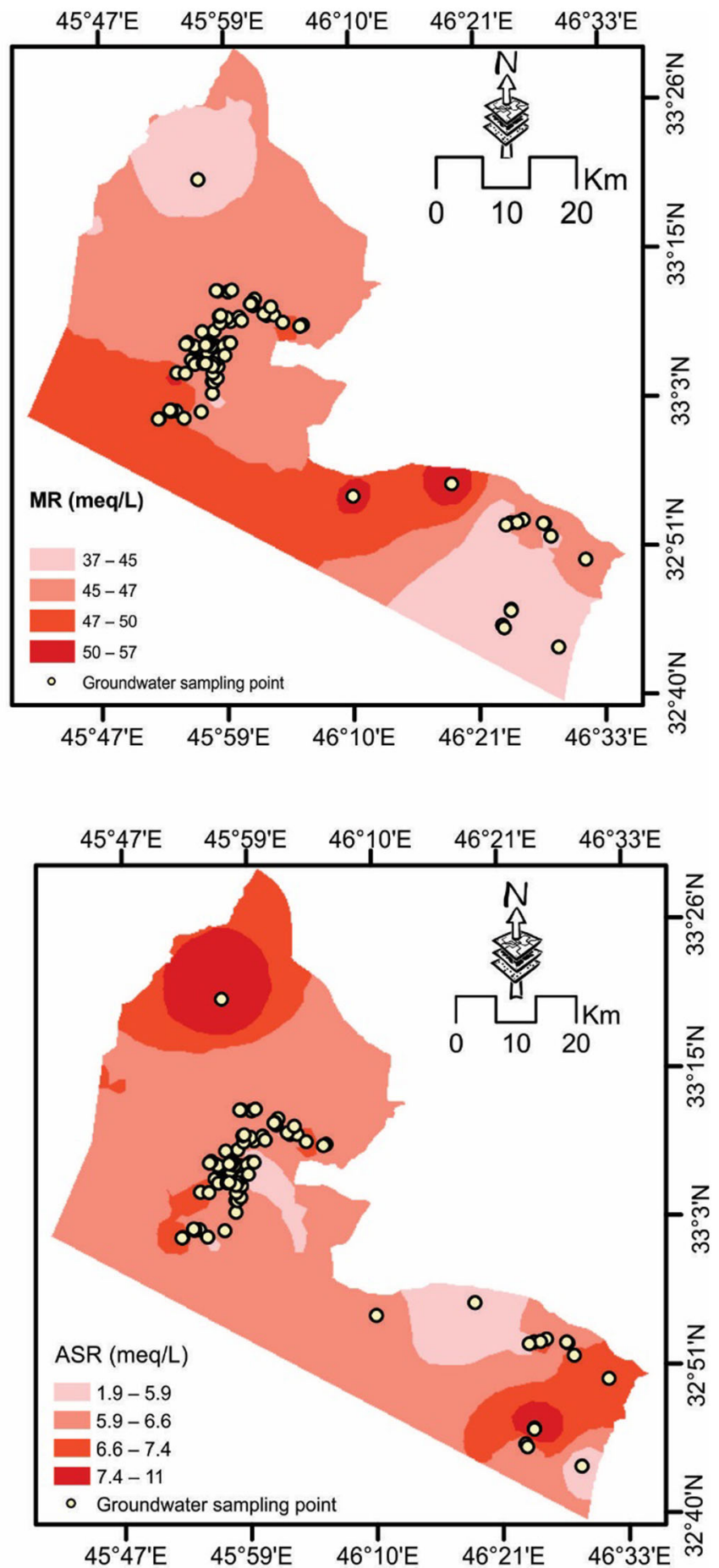

Fig. 15 The water quality zones to irrigation water quality for study area 
$\mathrm{Na}^{+}, \mathrm{Ca}^{2+}, \mathrm{Mg}^{2+}$ and $\mathrm{HCO}_{3}{ }^{-}$contents of the soil. The permeability index (PI), as developed by Doneen (1962) indicates the suitability of groundwater for irrigation. The permeability index was calculated employing the following equation, where all the ions are expressed in $\mathrm{meq} / \mathrm{L}$ :

$\mathrm{PI}=\frac{\left(\mathrm{Na}^{+}+\sqrt{\mathrm{HCO}_{3}^{-}}\right)}{\left(\mathrm{Ca}^{2+}+\mathrm{Mg}^{2+}+\mathrm{Na}^{+}\right)} \times 100$

According to permeability indices, the groundwater may be divided into class I, II and III. Class I and II water are categorised as good for irrigation with $75 \%$ or more of maximum permeability. Class III water is unsuitable with $25 \%$ of maximum permeability. According to permeability indices the groundwater may be divided into class I, II and III. Class I is categorised as excellent quality of water for irrigation with $75 \%$ or more of maximum permeability; Class II, if the PI values are between 25 and $75 \%$, indicates good quality of water for irrigation, whereas Class III, if the PI values are less than $25 \%$, reflects the unsuitable nature of water for irrigation. According to the permeability index values, $95.52 \%$ of the samples fall under the class 2 category and $4.48 \%$ of the samples fall in the Class 1 category, indicating that waters are suitable for irrigation.

\section{Magnesium ratio (MR)}

The MR value is the excess amount of magnesium over calcium and magnesium. An excess of $\mathrm{Mg}$ affects the quality of the soil, resulting in poor agricultural returns. Paliwal (1972) introduced a ratio called index of magnesium hazard. Magnesium hazard value of more than $50 \%$ would adversely affect the crop yield as the soils become more alkaline. MR was calculated by means of the following equation:

$\mathrm{MR}=\left[\mathrm{Mg}^{2+} /\left(\mathrm{Mg}^{2+}+\mathrm{Ca}^{2+}\right)\right] \times 100$,

where all the concentrations are expressed in meq/L. In the study area, the MR values ranged from 37.87 to $56.85 \mathrm{meq} /$ $\mathrm{L}$ with an average value of $46.33 \mathrm{meq} / \mathrm{L}$ (Table 2). The MR of 85.10 of the groundwater samples was considered suitable for irrigation (i.e., $\mathrm{MR}<50 \%$ ); meanwhile, $14.93 \%$ of samples were considered unsuitable (i.e., MR $>50 \%$ ), indicating their adverse effect on crop yields.

Generally, the map of groundwater suitability for irrigation shows that groundwater from all selected wells are suitable for irrigation purposes (Fig. 15). The best groundwater quality for irrigation usage concentrates in the central part of the analysed area.

\section{Conclusions}

The study shows a variety of groundwater types and salinities, and the dominant factors in controlling the groundwater hydrogeochemistry are evaporation and weathering in the study area. The result of this study showed that the sequence of the major cations and anions in the groundwater samples is $\mathrm{Na}^{+}>\mathrm{Ca}^{2+}>\mathrm{Mg}^{2+}>\mathrm{K}^{+}$ and $\mathrm{SO}_{4}{ }^{2-}>\mathrm{Cl}^{-}>\mathrm{HCO}_{3}{ }^{-}$. The alkali metal (Na) exceeds the alkaline earths $\left(\mathrm{Ca}^{2+}\right.$ and $\left.\mathrm{Mg}^{2+}\right)$ and strong acidic anions $\left(\mathrm{SO}_{4}{ }^{2-}\right.$ and $\left.\mathrm{Cl}^{-}\right)$exceed the weak acidic anion $\left(\mathrm{HCO}_{3}{ }^{-}\right)$. High $\mathrm{EC}$, TDS, $\mathrm{SO}_{4}$ and $\mathrm{Cl}$ concentrations are observed in the study area. Spatial distribution of electrical conductivity and major ions show large variations and generally increased in southwestern and southeastern the study area. The hydrogeochemical facies in the study area are divided into three major groups: Mixed $\mathrm{CaMgCl}$ type followed by $\mathrm{Na}^{+}-\mathrm{Cl}^{-}-\mathrm{SO}_{4}{ }^{2-}$ type and $\mathrm{Ca}^{2+}-\mathrm{Mg}^{2+}-\mathrm{Cl}^{-}-\mathrm{SO}_{4}{ }^{2-}$ type. Based on hydrochemical studies, the concentrations of cations and anions are far above the maximum acceptable levels for drinking water according to IQS 2009 and WHO 2011. Based on geochemical modelling results show that groundwater samples are under-saturated with respect to the evaporate minerals and saturated to oversaturated with respect to carbonate minerals. Regarding the classification of irrigation water according to RSBC values, all the samples collected were found to be satisfactory. According to PI values, all the samples are good for irrigation purposes. Based on the classification of irrigation water according to $\mathrm{MH}$ values, $85.10 \%$ of the samples can be categorized as suitable for irrigation. As a result of the arid climate, the indiscriminate exploitation of groundwater and recent drought salinity of groundwater in the study area have remarkably increased. Urgent management plans are needed to supervise the exploitation of groundwater resources and prevent further deterioration of groundwater quality.

Acknowledgements The authors are grateful to two anonymous reviewers and Prof. Dr. Alaa M. Al Abadi for valuable and constructive comments. Data support for this project was provided from the Groundwater foundation in Missan governorate. Head of Groundwater foundation in Missan Mr. Ahmed AL Saeedi and assistants in various field and analytical works are also highly appreciated.

Open Access This article is distributed under the terms of the Creative Commons Attribution 4.0 International License (http:// creativecommons.org/licenses/by/4.0/), which permits unrestricted use, distribution, and reproduction in any medium, provided you give appropriate credit to the original author(s) and the source, provide a link to the Creative Commons license, and indicate if changes were made. 


\section{References}

Hassan H et al (1977) Galal Badra poject area, part I-IV. Inst. For Applied Research on Natural Resources Techn Bull 106

Al Sayab A, Hassan H, Ayob M, Taha S, Salih A, Faizi K (1983) Water-salt balance and supplementary Irrigation of Alton Copry Basin, Tech Rep. No. 14811 SRC, p 89

Al-Abadi A (2012) Hydrological and hydrogeological analysis of northeaster Missan Governorate, south of Iraq using Geographic Information System. Doctoral Thesis, Baghdad University

Al-Abadi A (2015) Modeling of groundwater productivity in northeastern Wasit Governorate, Iraq by using frequency ratio and Shannon's entropy models. Appl Water Sci. doi:10.1007/ s13201-015-0283-1

Alam M, Rais S, Aslam M (2012) Hydrochemical investigation and quality assessment of ground water in rural areas of Delhi. India Environ Earth Sci 66:97-110

Al-Azawi BM (2002) Hydrogeological properties of Groundwater System in BadraJassan basin. M.Sc Thesis Baghdad University Unpublished, p 100

Al-Furat Center Company for study and design irrigation projects (2002) Hydrogeological Investigations, Fifth order, Badra-Jassan Area, Wasit, Iraq, Final Report, p 67

Ali SM, Ali AH (2013) Hydrochemistry and geochemical evolution of unconfined aquifer in Kalal Badrah Basin, Wasit, East of Iraq vol. 3 , p 16

Al-Shammary SH (2006) Hydrogeology of Galal Basin, Wasit, east of Iraq. PhD Thesis, Baghdad University, Iraq (unpublished)

APHA (1998) Standard methods for the examination of water and wastewater, 20th edn. American Public Health Association, Washington

Appelo CAJ, Postma D (2004) Geochemistry, groundwater and pollution. CRC Press, Boca Raton

Bhatia H (2003) A textbook on environmental pollution and control. Galgotia Publications Private Limited, Delhi

Bozdağ A (2015) Combining AHP with GIS for assessment of irrigation water quality in Çumra irrigation district (Konya), Central Anatolia, Turkey. Environ Earth Sci 73:8217-8236

Bozdağ A, Göçmez G (2013) Evaluation of groundwater quality in the Cihanbeyli basin, Konya, Central Anatolia, Turkey. Environ Earth Sci 69:921-937. doi:10.1007/s12665-012-1977-4

Collins R, Jenkins A (1996) The impact of agricultural land use on stream chemistry in the middle hills of the Himalayas, Nepal. J Hydrol 185:71-86

Delgado C, Pacheco J, Cabrera A, Batllori E, Orellana R, Bautista F (2010) Quality of groundwater for irrigation in tropical karst environment: the case of Yucatan, Mexico. Agric Water Manag 97:1423-1433

Detay M, Carpenter M (1997) Water wells: implementation, maintenance and restoration. Wiley, London

Domenico PA, Schwartz FW (1998) Physical and chemical hydrogeology, vol 506. Wiley, New York

Doneen L (1962) The influence of crop and soil on percolating water. In: Proceeding 1961 biennial conference on groundwater recharge, pp 156-163

Durov SA (1948) Natural waters and graphic representation of their composition. Dokl Akad Nauk SSSR 59:87-90

Edmunds W, Ma J, Aeschbach-Hertig W, Kipfer R, Darbyshire D (2006) Groundwater recharge history and hydrogeochemical evolution in the Minqin Basin. North West China Appl Geochem 21:2148-2170

Enad TH (2007) Stratigraphic and sedimentologic study of the Mukdadiya Formation in Badra area Wasit Provinance Unpublished. MSc.Thesis, Baghdad University, p 136
Esmaeili A, Moore F (2012) Hydrogeochemical assessment of groundwater in Isfahan province, Iran. Environ Earth Sci 67:107-120

Freeze RA, Cherry JA (1979) Groundwater. Prentice-Hall, Englewood Cliffs, p 604

Ghalib HB, Söğüt AR (2014) Environmental isotopic characterization of groundwater and surface water in northeast Missan Province, South Iraq. Acta Geol Sinica 88:1227-1238

Gibbs RJ (1970) Mechanisms controlling world's water chemistry, volt. Science 170:1088-1090

Guendouz A, Moulla A, Edmunds W, Zouari K, Shand P, Mamou A (2003) Hydrogeochemical and isotopic evolution of water in the Complexe Terminal aquifer in the Algerian Sahara. Hydrogeol J 11:483-495

Gupta SK, Gupta IC (1987) Management of saline soils and waters. Oxford \& IBH Pub. Co., New Delhi

Hassan HA (1985) Regional photogeological and geomorphological mapping of Mandali, Badra, Zurbatiya, Al-Tib Area, Internal Report, Geosur Library, Baghdad, No. 1378, p 19

Hem JD (1985) Study and interpretation of the chemical characteristics of natural water vol 2254. Department of the Interior, US Geological Survey

IQS (2009) Iraqi Standard of Drinking Water No. 417 Second modification

Jassim SZ, Goff JC (2006) Geology of Iraq. Dolin; Moravian Museum, Prague; Brno

Kalra YP, Maynard DG (1991) Methods manual for forest soil and plant analysis

Kumar M, Kumari K, Ramanathan A, Saxena R (2007) A comparative evaluation of groundwater suitability for irrigation and drinking purposes in two intensively cultivated districts of Punjab, India. Environ Geol 53:553-574

Lee RW (1993) Geochemistry of ground water in the southeastern coastal plain aquifer system in Mississippi, Alabama, Georgia, and South Carolina. US Government Printing Office

Lloyd JW, Heathcote JA (1985) Natural inorganic hydrochemistry in relation to groundwater an introduction. Clarendon Press, Oxford University Press, New York

Macfadyen WA (1935) Water supply in Iraq. Publication No. 1, Study of certain springs in the Altun Kupri basin, Baghdad, Iraq

Magesh N, Krishnakumar S, Chandrasekar N, Soundranayagam JP (2013) Groundwater quality assessment using WQI and GIS techniques, Dindigul district, Tamil Nadu, India. Arab J Geosci 6:4179-4189. doi:10.1007/s12517-012-0673-8

Mitra B, Sasaki C, Enari K, Matsuyama N, Fujita M (2007) Suitability assessment of shallow groundwater for agriculture in sand dune area of northwest Honshu Island Japan. Appl Ecol Environ Res 5:177-188

Ophori D, Toth J (1989) Patterns of ground-water chemistry, Ross Creek Basin, Alberta, Canada. Ground Water 27:20-26

Paliwal KV (1972) Irrigation with saline water

Parkhurst DL, Appelo C (2013) Description of input and examples for PHREEQC version 3-a computer program for speciation, batch-reaction, one-dimensional transport, and inverse geochemical calculations US geological survey techniques and methods, book 6, p 497

Parson RM (1955) Groundwater resource of Iraq, vol. 4 Kirkuk liwa Development Board Ministry of Development Government of Iraq, p 142

Parsons RM (1956) Ground-water resources of Iraq, Khanaqin-Jassan Area (vol. 1). Development Board, Ministry of Development Government of Iraq, Baghdad

Piper AM (1944) A graphic procedure in the geochemical interpretation of water-analyses. Eos Trans Am Geophys Union 25:914-928 
Prasanna MV, Chidambaram S, Srinivasamoorthy K (2010) Statistical analysis of the hydrogeochemical evolution of groundwater in hard and sedimentary aquifers system of Gadilam river basin, South India. J King Saud Univ Sci 22:133-145

Prasanth SS, Magesh N, Jitheshlal K, Chandrasekar N, Gangadhar K (2012) Evaluation of groundwater quality and its suitability for drinking and agricultural use in the coastal stretch of Alappuzha District, Kerala, India. Appl Water Sci 2:165-175

Raju NJ (2007) Hydrogeochemical parameters for assessment of groundwater quality in the upper Gunjanaeru River basin, Cuddapah District, Andhra Pradesh, South India. Environ Geol 52:1067-1074

Raju NJ, Shukla U, Ram P (2011) Hydrogeochemistry for the assessment of groundwater quality in Varanasi: a fast-urbanizing center in Uttar Pradesh, India. Environ Monit Assess 173:279-300

Ramesh K, Elango L (2012) Groundwater quality and its suitability for domestic and agricultural use in Tondiar river basin, Tamil Nadu, India. Environ Monit Assess 184:3887-3899

Ranjan RK, Ramanathan A, Parthasarathy P, Kumar A (2013) Hydrochemical characteristics of groundwater in the plains of Phalgu River in Gaya, Bihar, India. Arab J Geosci 6:3257-3267. doi:10.1007/s12517-012-0599-1

Rao NS, Rao JP, Devadas DJ, Rao KS (2002) Hydrogeochemistry and groundwater quality in a developing urban environment of a semi-arid region, Guntur, Andhra Pradesh. Geol Soc India 59:159-166

Sahinci A (1991) Geochemistry of natural waters (in Turkish). Izmir: Reform printing office, p 548

Saleh A, Al-Ruwaih F, Shehata M (1999) Hydrogeochemical processes operating within the main aquifers of Kuwait. J Arid Environ 42:195-209

Salifu M, Aidoo F, Hayford MS, Adomako D, Asare E (2015) Evaluating the suitability of groundwater for irrigational purposes in some selected districts of the Upper West region of Ghana. Appl Water Sci 1-10

Stumm W, Morgan JJ (2012) Aquatic chemistry: chemical equilibria and rates in natural waters, vol 126. Wiley, New York

Subramani T, Elango L, Damodarasamy S (2005) Groundwater quality and its suitability for drinking and agricultural use in Chithar River Basin, Tamil Nadu, India. Environ Geol 47:1099-1110

Todd DK (2009) Groundwater hydrology. Wiley, New delhi, India

USDA (1986) United States Department of Agriculture, Soil Conservation Service. Urban hydrology for small watersheds, Technical release no. 55, 2nd edn. Washington, DC

WHO G (2011) Guidelines for drinking-water quality. World Health Organization 216:303-304

Wilcox LV (1948) The quality of water for irrigation use. United States Department of Agriculture, Economic Research Service

Wilcox L (1955) Classification and use of irrigation waters 